\title{
Phytochemical and Pharmacological Support for the Traditional Uses of Zingiberacea Species in Suriname - A Review of the Literature
}

\author{
Dennis RA Mans*, Meryll Djotaroeno, Priscilla Friperson, Jennifer Pawirodihardjo
}

Dennis RA Mans*, Meryll

Djotaroeno, Priscilla Friperson, Jennifer Pawirodihardjo

Department of Pharmacology, Faculty of Medical Sciences, Anton de Kom University of Suriname, Paramaribo, SURINAME.

\section{Correspondence}

\section{Dennis RA Mans}

Department of Pharmacology, Faculty of Medical Sciences, Anton de Kom University of Suriname, Kernkampweg 6, Paramaribo, SURINAME.

Phone no: 597441071

E-mail: dennismans16@gmail.com History

- Submission Date: 01-10-2019;

- Review completed: 13-10-2019;

- Accepted Date: 14-10-2019.

DOI : 10.5530/pj.2019.11.232

Article Available online http://www.phcogj.com/v11/i6s

\section{Copyright}

(C) 2019 Phcogi.Com. This is an openaccess article distributed under the terms of the Creative Commons Attribution 4.0 International license.

\begin{abstract}
The Zingiberacea or ginger family is a family of flowering plants comprising roughly 1,600 species of aromatic perennial herbs with creeping horizontal or tuberous rhizomes divided into about 50 genera. The Zingiberaceae are distributed throughout tropical Africa, Asia, and the Americas. Many members are economically important as spices, ornamentals, cosmetics, traditional medicines, and/or ingredients of religious rituals. One of the most prominent characteristics of this plant family is the presence of essential oils in particularly the rhizomes but in some cases also the leaves and other parts of the plant. The essential oils are in general made up of a variety of, among others, terpenoid and phenolic compounds with important biological activities. The Republic of Suriname (South America) is well-known for its ethnic and cultural diversity as well as its extensive ethnopharmacological knowledge and unique plant biodiversity. This paper first presents some general information on the Zingiberacea family, subsequently provides some background about Suriname and the Zingiberacea species in the country, then extensively addresses the traditional uses of one representative of the seven genera in the country and provides the phytochemical and pharmacological support for these uses, and concludes with a critical appraisal of the medicinal values of these plants.

Key words: Zingiberaceae, Suriname, Traditional uses, Rationale, Phytochemical composition, Pharmacological activity.
\end{abstract}

\section{INTRODUCTION}

The plant family Zingiberaceae or ginger family includes about 50 genera and roughly 1,600 known species of flowering perennial plants that are distributed throughout tropical Africa, Asia, and the Americas. ${ }^{1}$ The highest diversity is encountered in south-eastern Asia, and the greatest concentration in the north-eastern region of India with 19 genera and 88 species. ${ }^{1}$ The majority of the Zingiberacea members grows in humid and shady places. ${ }^{1}$ Most are small to large herbaceous plants with distichous leaves having basal sheaths that overlap to form a pseudostem. ${ }^{1}$ They are characterized by aromatic and creeping horizontal or tuberous rhizomes, hermaphroditic flowers consisting of a single functional stamen (the pollen-producing part of the flower) that runs through the pistil (the ovuleproducing part of the flower), and petals that are sterile stamina called staminodes. ${ }^{1}$

Many members of the Zingiberaceae are economically important as spices, ornamental plants, cosmetics, traditional medicines, and/or ingredients of religious rituals. The seeds from the genera Amomum Roxb. and Elettaria Maton give the spice cardamom, the world's third-most expensive spice in price per weight after vanilla and saffron. ${ }^{2}$ The rhizomes from the Thai ginger Alpinia galanga (L.) Willd., the turmeric Curcuma longa L., and the common ginger Zingiber officinale Roscoe are well-known spices, condiments, and flavoring compounds. ${ }^{3}$ And the leaves and flowers from $C$. longa, the grains of paradise Aframomum melegueta K. Schum., the white ginger Hedychium coronarium J. Koenig, and the east-Indian galangal Kaempferia galanga L. are consumed as vegetables and used as key ingredients of spicy savory dishes and/or herbal teas. $^{3}$

Various species in the genera Alpinia Roxb., 1810, Curcuma L., Globba L., Hedychium J. Koenig, Kaempferia L., and Renealmia L.f. have visually attractive flowers and inflorescences and are cultivated as ornamentals. ${ }^{3}$ The rhizomes from many species in the genera Alpinia Roxb., 1810, Curcuma L., Hedychium J. Koenig, and Zingiber Mill., 1754 contain essential oils for producing soaps, cosmetics, and perfumes. ${ }^{3}$ In addition, a number of ginger species are medicinally used in various traditional systems throughout the world. Examples are $A$. melegueta, C. longa, and Z. officinale, preparations of which are used for treating many diseases ranging from infectious diseases and inflammatory conditions to hypertension and diabetes mellitus. ${ }^{4}$ Parts from A. melegueta, C. longa, and R. alpinia are also used in religious ceremonies. ${ }^{3}$

This paper first presents some general information about the Zingiberacea family, subsequently provides some background on Suriname, then extensively addresses the traditional uses of one representative species of the seven Zingiberacea genera in the 
country as well as the phytochemical and pharmacological support for these uses, and concludes with a critical appraisal of the medicinal value of these plants.

\section{BACKGROUND}

\section{General aspects of Suriname}

The Republic of Suriname is located on the north-east coast of South America between French Guiana and Guyana and borders the Atlantic Ocean to the north and Brazil to the south. It is the smallest and least populated country in South America, occupying a land area of roughly $165,000 \mathrm{~km}^{2}$ and harboring an estimated 590,000 inhabitants. ${ }^{5}$ Roughly $80 \%$ of the population lives in the relatively narrow northern coastal zone while the remaining $20 \%$ populates the savannas and hinterlands in the interior of the country. ${ }^{5}$ Suriname's most important economic means of support are crude oil drilling, gold mining, agriculture, fisheries, forestry, and ecotourism. ${ }^{6}$ These activities have substantially contributed to the gross domestic income in 2017 of USD 2,996 billion and the average per capita income in that year of USD 5,150. ${ }^{6}$ This positions Suriname on the World Bank's list of upper-middle income economies. ${ }^{7}$

Despite its relatively small population, Suriname is one of the ethnically, religiously, culturally, and linguistically most diverse countries in the world. ${ }^{5}$ In addition to the original inhabitants, the Indigenous Amerindians, the country is home to the descendants from enslaved Africans from various African countries called Maroons, those of mixed black and white origin called Creoles; the descendants from indentured laborers from China, India (called Hindustanis), and the Indonesian island of Java (called Javanese), as well as those from several European and Middle Eastern countries. ${ }^{5}$ More recently, individuals from a number of Latin American and Caribbean countries including Brazil, Guyana, French Guiana, the Netherlands Antilles, Haiti, Cuba, and Venezuela have settled in Suriname. ${ }^{5}$

\section{Traditional medicine in Suriname}

The various ethnic groups in Suriname have largely preserved their culture and identity, still practicing their original religion and speaking their original language in addition to Dutch (the official language) and Surinamese or Sranan Tongo. ${ }^{5,8}$ The same holds true for their specific perceptions of health and disease, ethnopharmacological traditions, and traditional medical concepts. ${ }^{8}$ This was probably partially due to the divide-and-conquer policy of the colonial government which kept the several groups isolated, and partially to the desire of each ethnic group to adhere to its particular customs as a means of strengthening the own identity in the new and unfamiliar environment of Suriname. ${ }^{8}$

Important factors which helped preserve the various traditional medical systems were the extensive botanical knowledge of the newcomers and their previous acquaintance with useful plants. Indeed, the newcomers readily recognized many edible and medicinal plants in Suriname because these plants, along with numerous commodities, people, animals, and diseases had been transferred from the Old World (Europe, Asia, and Africa) to the New World (the Americas) and vice versa during the Columbian Exchange in the $15^{\text {th }}$ and $16^{\text {th }}$ centuries. ${ }^{9}$ A few of many examples of such plants were maize (Zea mays L. (Poaceae)), cassava (Manihot esculenta Crantz (Euphorbiaceae)), okra (Abelmoschus esculentus (L.) Moench (Malvaceae)), and sesame (Sesamum indicum L. (Pedaliaceae)). ${ }^{9}$ Z. mays and M. esculenta were native to South America and had been introduced in Africa in the $16^{\text {th }}$ century, while $A$. esculentus and $S$. indicum had been brought to Suriname from Africa. ${ }^{9}$

Furthermore, the enslaved African and Asian indentured laborers cultivated several food crops and medicinal plants from leftovers of the meals they were given during the trans-Atlantic journey. ${ }^{8} \mathrm{~A}$ well-established example is the African rice Oryza glaberrima Steud. (Poaceae) that has probably been introduced in Suriname by enslaved African women who prepared meals on the slave ships and intentionally collected rice seeds. ${ }^{10}$ The new arrivals also grew useful plants from plant parts they had brought along from their home country to Suriname to prepare their specific foods, traditional medicines, cosmetics, and ritual artefacts. ${ }^{8}$ A few examples are the tamarind Tamarindus indica L. (Fabaceae), the milkvetch or huáng qí Astragalus propinquus Schischkin (Fabaceae), the neem plant Azadirachta indica A. Juss., 1830 (Meliaceae), and the cat's whiskers or kumis kutying Orthosiphon stamineus Bold. (Lamiaceae). ${ }^{11}$ These plants are important in African traditional medicine, Chinese traditional medicine, Indian Ayurveda, and Javanese Jamu, respectively. ${ }^{11}$

\section{Zingiberaceae species in Suriname}

In addition to the above-mentioned plant species and many others, several members of the Zingiberaceae family have been introduced into Suriname. ${ }^{12-15}$ They are commonly used for preparing condiments and soft drinks, as spices in food, for medicinal purposes, and in ritual practices. ${ }^{12-15}$ A. melegueta and $H$. coronarium, for instance, originate from Africa where they had considerable economic and medicinal significance, and have probably been brought to Suriname and popularized in the country by enslaved Africans and their descendants. ${ }^{16} \mathrm{C}$. longa and $\mathrm{H}$. coronarium are important plants in Indian Ayurveda and are associated with Hindustani indentured workers and their children ${ }^{17}$, and A. alpinia as well as $K$. galanga presumably originate from Indonesia, where they have been for centuries important plants in Jawa traditional medical and cultural practices. ${ }^{14}$ Not surprisingly, particularly the Surinamese Javanese abundantly use Zingiberacea species in health supplements known as jamus. ${ }^{14}$

Only 7 of the 50 genera of the Zingiberaceae plant family are present in Suriname. These include the genera Aframomum, Alpinia, Curcuma, Hedychium, Kaempferia, Renealmia, and Zingiber. Table 1 shows a representative species of each genus that is commonly used in the country. Hereunder, the various applications of these plants including their traditional medical uses are in detail addressed, and the scientific support for these uses is provided on the basis of available phytochemical and pharmacological information.

\section{Aframomum melegueta K. Schum.}

The grains of paradise or Guinea pepper A. melegueta is native to the western African coast but is now cultivated in most African countries as well as parts of South America and the Caribbean including Suriname. The plant bears trumpet-shaped, purple flowers which develop into pods of 5 to 7 centimeters long (Figure 1) that contain many small, reddish-brown seeds. Between the $16^{\text {th }}$ and the $19^{\text {th }}$ century, the sharptasting seeds were in high demand in Europe as an alternative for the relatively expensive black pepper Piper nigrum L. (Piperaceae) from Asia. The thriving trade of $A$. melegueta seeds in that period is reflected by the name 'Pepper Coast' or 'Grain Coast' given to the coastal area of western Africa that was then one of the centers of A. melegueta cultivation and trade, and currently comprises the Republic of Liberia.

A. melegueta seeds are commonly used in western and northern African cuisines as a spicy seasoning for sausages and meats and as a flavoring for hot and cold beverages, ice cream, candy, and bread. In various other parts of the world, the seeds are used in gourmet cuisine as a replacement for pepper; to flavor certain craft beers, gins, and the Scandinavian alcoholic beverage akvavit; and as a condiment in exquisite dishes such as exclusive okra stews and apple pie recipes. $A$. melegueta seeds have also been used to provide a fictitious strength to alcoholic beverages, but this practice has been declared illegal and has been banned. 
Table 1: Representative Zingiberacea species in Suriname, their traditional medical uses, and the phytochemical and pharmacological support for these uses.

\begin{tabular}{|c|c|c|c|}
\hline $\begin{array}{l}\text { Plant species } \\
\text { (vernacular names in } \\
\text { English; Surinamese/ } \\
\text { Javanese/Hindustani/ } \\
\text { Dutch) }\end{array}$ & Traditional medicinal uses & Phytochemical composition & Pharmacologcial activities \\
\hline $\begin{array}{l}\text { Aframomum melegueta } \\
\text { (Roscoe) K. Schum. } \\
\text { (grains of paradise; } \\
\text { nengrekondre pepre) }\end{array}$ & $\begin{array}{c}\text { Respiratory tract infections, gastrointestinal } \\
\text { problems, snakebites and scorpion stings, } \\
\text { cancer, infertility, hypertension, diabetes } \\
\text { mellitus }^{8,14,15}\end{array}$ & $\begin{array}{l}\text { Arylalkanoids such as paradols, shogaols, } \\
\text { and gingerols, labdane diterpenoids such } \\
\text { as zerumin A, sesquiterpenes such as } \\
\text { humulene and caryophyllene, flavonoids } \\
\text { such as quercetin and kaempferol }{ }^{16,17}\end{array}$ & $\begin{array}{l}\text { Antimicrobial, }{ }^{19-22} \text { antiparasitic, }{ }^{24,25} \\
\text { antiinflammatory, }{ }^{23} \text { anticancer and } \\
\text { chemopreventive activity, }{ }^{28-31} \text { blood } \\
\text { pressure-lowering, }{ }^{36} \text { hypoglycemic } \\
\text { activity; }{ }^{37} \text { (male) fertility booster; }{ }^{32,33} \\
\text { abortifacient }{ }^{35}\end{array}$ \\
\hline $\begin{array}{l}\text { Alpinia galanga (L.) Willd. } \\
\text { (Thai ginger; laos) }\end{array}$ & $\begin{array}{l}\text { Microbial infections, HIV infection, } \\
\text { rheumatic disorders, gastrointestinal } \\
\text { ailments, headache and body aches }\end{array}$ & $\begin{array}{l}\text { Phenylpropanoids such as } 1 \text { 'S'-1'- } \\
\text { acetoxychavicol acetate, terpenes/ } \\
\text { terpenoids such as } \beta \text {-pinene, flavonoids } \\
\text { such as galangin and alpinin }{ }^{43,44}\end{array}$ & $\begin{array}{l}\text { Antimicrobial, }{ }^{46-50} \text { anti-HIV, } \\
\text { antiparasitic, } \\
\text { ant,53 antiinflammatory, } \\
\text { antiulcer, }{ }^{58,59} \text { hepatoprotective activity }\end{array}$ \\
\hline $\begin{array}{l}\text { Curcuma longa L. } \\
\text { (turmeric; haldi/kunyit) }\end{array}$ & $\begin{array}{l}\text { Inflammations, precancerous conditions } \\
\text { and cancer, microbial infections, brain } \\
\text { disorders such as depression and } \\
\text { Alzheimer's disease } \mathrm{e}^{7,8,13,63,64}\end{array}$ & $\begin{array}{l}\text { Diarylheptanoids including curcuminoids } \\
\text { such as curcumin, diarylpentanoids, } \\
\text { sesquiterpenes, monoterpenes, diterpenes, } \\
\text { and triterpenoids }{ }^{65-67}\end{array}$ & $\begin{array}{l}\text { Antinflammatory, }{ }^{68-83} \text { chemopreventive and } \\
\text { anticancer, }{ }^{85-92} \text { antimicrobial, }{ }^{62,93-95} \\
\text { Antiparasitic, }{ }^{96} \text { anti-Alzheimer activity }{ }^{97-99}\end{array}$ \\
\hline $\begin{array}{l}\text { Hedychium coronarium J. } \\
\text { König } \\
\text { (white butterfly ginger; } \\
\text { gember lelie) }\end{array}$ & $\begin{array}{l}\text { Microbial infections, parasitic infections, } \\
\text { inflammatory complaints, cancer }{ }^{104,105}\end{array}$ & $\begin{array}{l}\text { Labdane diterpenes such as, coronarins, } \\
\text { farnesane sesquiterpenes such as nerolidol } \\
\text { and hedychiols, monoterpenes such as } \\
1,8 \text {-cineole and } \alpha \text { - and } \beta \text {-pinene }{ }^{107-109}\end{array}$ & $\begin{array}{l}\text { Antimicrobial, }{ }^{110-115} \text { antiparasitic, }{ }^{112,115,116} \\
\text { antiinflammatory and analgesic, }{ }^{117-120} \\
\text { anticancer and chemopreventive } \\
\text { activity }\end{array}$ \\
\hline $\begin{array}{l}\text { Kaempferia galanga (L.) } \\
\text { Willd. } \\
\text { (East-Indian galangal; } \\
\text { kentyur) }\end{array}$ & $\begin{array}{l}\text { Microbial infections, inflammatory } \\
\text { conditions, parasitic infections, headaches, } \\
\text { mouth ulcers, toothache, dermatological } \\
\text { problems, anxiety and depression }\end{array}$ & $\begin{array}{l}\text { Phenylpropanoids such as ethyl p-methoxy } \\
\text { cinnamate; flavonols such as kaempferol; } \\
\text { terpenoids such as } 1,8 \text { - } \text { cineole }^{129,130}\end{array}$ & $\begin{array}{l}\text { Antimicrobial, }{ }^{131-143} \text { antiparasitic, }{ }^{136-143} \\
\text { antiinflammatory, antinociceptive, and } \\
\text { sedative activity }{ }^{144-150}\end{array}$ \\
\hline $\begin{array}{l}\text { Renealmia alpinia (Rottb.) } \\
\text { Maas } \\
\text { (ink plant; bigi masusa) }\end{array}$ & $\begin{array}{l}\text { Snake bites and scorpion stings, } \\
\text { bacterial infections, gastrointestinal } \\
\text { problems, fungal infections, convulsions } \\
\text { and seizures, }{ }^{8,151-154,172} \text { anxiety, }{ }^{170} \\
\text { neurodegenerative disturbances }{ }^{171}\end{array}$ & $\begin{array}{l}\text { Monoterpenes such as } \beta \text {-pinene; labdane } \\
\text { diterpenoids; diarylheptanoids; phenolic } \\
\text { compounds such as coumarins and } \\
\text { pinostrobin; desmethoxyyangonin }{ }^{155-158}\end{array}$ & $\begin{array}{c}\text { Antivenom, }{ }^{152,159,160,162} \text { analgesic, } \\
\text { antinociceptive, and anti-inflammatory, } \\
\text { antimicrobial, }{ }^{163-165} \text { antiparasitic, }{ }^{116,165} \text { MAO- } \\
\text { inhibitory activity }{ }^{169}\end{array}$ \\
\hline $\begin{array}{l}\text { Zingiber officinale Roscoe } \\
\text { (common ginger; dyindya) }\end{array}$ & $\begin{array}{c}\text { Nausea and vomiting, microbial infections, } \\
\text { parasitic infections, inflammatory } \\
\text { conditions }{ }^{176-178}\end{array}$ & $\begin{array}{c}\text { Sequiterpene hydrocarbons such as } \\
\text { zingiberol; }{ }^{179} \text { phenolic compounds such } \\
\text { as gingerols, shogaols, paradols, and } \\
\text { zingerone }{ }^{179,180}\end{array}$ & $\begin{array}{c}\text { Antiemetic, }{ }^{182-185,188,189} \text { antimicrobial, }{ }^{191-193} \\
\text { antiparasitic, }{ }^{194-197} \text { antiinflammatory and } \\
\text { analgesic activity }{ }^{198-202}\end{array}$ \\
\hline
\end{tabular}

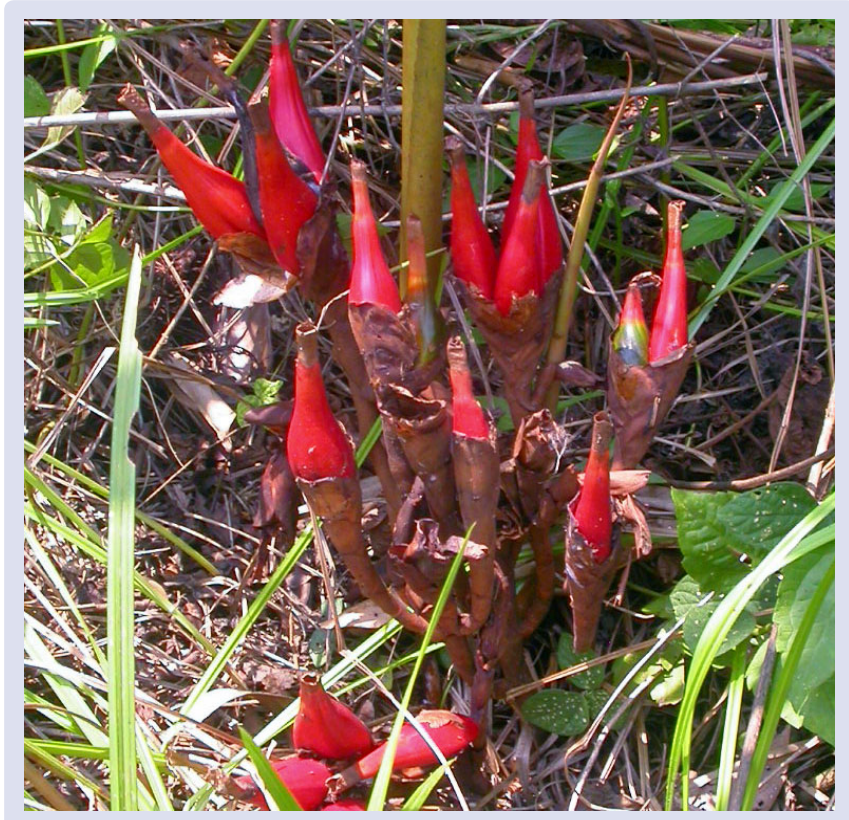

Figure 1: Seed pods of Aframomum melegueta (Roscoe) K. Schum. (from: https://images.app.goo.gl/7i3LE4owB5vwjDJx7).
A. melegueta has a long traditional medical use in Africa and Afro-American communities including those of the Surinamese Maroons where it is known as 'nengrekondre pepre' ('pepper from the homeland of the Africans'). Seed preparations are used, among others, against infections and inflammations of the respiratory tract and the gastrointestinal system; to repel pests of stored grains; to fight cancer; for treating infertility; and against hypertension and diabetes mellitus. ${ }^{15,18,19}$ A hot-water infusion of the seeds would also help against stuttering when drunk from the larynx of a howler monkey or a large snail shell ${ }^{12}$, and an alcoholic extraction would serve as an aphrodisiac. ${ }^{15}$ A. melegueta seeds are, furthermore, essential components of Maroon rituals and herbal baths to exorcise evil spirits and neutralize witchcraft, but also in practices to attract good fortune. ${ }^{15}$

Important phytochemicals in A. melegueta seeds, seed extracts, and the seed essential oil are arylalkanoids such as paradols, shogaols, and gingerols, the aromatic ketones responsible for the strong aromatic flavor and pungent, peppery taste associated with the plant. ${ }^{20}$ Other phytochemicals in the seeds are labdane diterpenoids such as zerumin $\mathrm{A}$ and (E)-labda 8(17),12-diene-15,16-dial; sesquiterpene hydrocarbons such as humulene and caryophyllene; and flavonoids such as quercetin and kaempferol and their derivatives. ${ }^{20,21}$ Of note, the relative abundance and diversity of flavonoids, diterpenoids, and sesquiterpenoids may represent a chemotaxonomic marker of the genus Aframomum, distinguishing it from other genera in the Zingiberaceae. ${ }^{22}$ 
The traditional use of $A$. melegueta against respiratory tract infections is supported by the meaningful antibacterial and antifungal activity (including activity against methicillin-resistant Staphylococus aureus (MRSA)) of preparations and constituents of the seeds and rhizomes. ${ }^{23,24}$ These effects were also achieved with various flavonoids, terpenoids, as well as 6-paradol and related compounds isolated from these parts of the plant. ${ }^{24,25}$ In addition, the seed essential oil inhibited the in vitro proliferation of Bacillus cereus, an important causative agent of foodborne illness. ${ }^{26}$ An ethanolic seed extract also reduced paw edema in laboratory rats in a process involving inhibition of cyclooxygenase-2 (COX-2) activity, ${ }^{27}$ and 6-paradol and 6-shogaol stimulated the expression of proinflammatory genes in an assay for proinflammatory gene expression. ${ }^{27}$ These findings are in accordance with the traditional use of A. melegueta against inflammatory conditions.

Indications for the usefulness of $A$. melegueta seed extracts as well as 6-gingerol and 6-shogaol against pests of stored foods are provided by the repellent activity of both the seed extract and (S)-2-heptanol, (S)2-heptyl acetate, and (R)-linalool against the maize weevil Sitophilus zeamais, an infamous agricultural pest. ${ }^{28}$ These substances also elicited antifeedant activity towards the subterranean termite Reticulitermes speratus that is considered an urban pest of wooden constructions in Japan. ${ }^{29}$ These observations provide a tentative explanation for the preference of wild western lowland gorillas to eat this plant and use it to make the nests where they sleep at night. ${ }^{30}$ This behavior presumably protects them from a bacterial or a viral infection that would cause fibrosing cardiomyopathy, a common cause of heart failure and/or sudden death in these animals. ${ }^{30}$

Indications for potential antitumor activity of A. melegueta were provided by the inhibitory effects of 6-paradol as well as organic extracts of the rhizome on the proliferation of various human tumor cell lines (see, for instance ${ }^{31}$ ). The cytotoxic effects were accompanied by signs of apoptosis ${ }^{31}$, possibly through a caspase-3-dependent pathway ${ }^{31}$. Evidence for chemopreventive properties of $A$. melegueta came from the inhibitory effects of 6-paradol and/or some of its synthetic derivatives on the promotion of skin carcinogenesis and ear edema in ICR mice induced by the laboratory tumor promoter phorbol 12-myristate 13-acetate (PMA). ${ }^{32}$ Furthermore, these compounds led to a reduction in frequency and number of skin tumors caused by the laboratory carcinogen 7,12-dimethylbenz[a]anthracene and promoted by PMA as well as the induction of PMA-induced ornithine decarboxylase activity in the animals. ${ }^{32} 6$-Paradol and its derivatives also led to a decrease in DNA damage in cultured cancer cells. ${ }^{32}$

The use of A. melegueta seed preparations for improving fertility in humans is supported by the stimulatory effect of an aqueous seed extract on mating behavior, sexual arousal, and reproductive function parameters in male Wistar rats ${ }^{33}$, and the increased testosterone levels in the animals following intaperitoneal injection of the seed oil. ${ }^{34} \mathrm{On}$ the other hand, administration of a seed extract to Sprague Dawley rats led to termination of first trimester pregnancy, ${ }^{35}$ suggesting that $A$. melegueta seed also has abortifacient properties.

Other reported pharmacological effects of A. melegueta include blood pressure-lowering activity of a seed preparation in both normotensive and hypertensive individuals, ${ }^{36}$ and the hypoglycemic activity of an aqueous leaf extract in alloxan-induced diabetic and non-diabetic rats through the stimulation of insulin secretion from remnant or regenerated pancreatic $\beta$ cells. ${ }^{37}$ These observations give some credit to the traditional use of $A$. melegueta seed preparations against hypertension and diabetes mellitus.

Alpinia galanga (L.) Willd.

The Thai ginger, java galangal, greater galangal, or laos Alpinia galanga (L.) Willd is one of four plants known as galangals or blue gingers. It

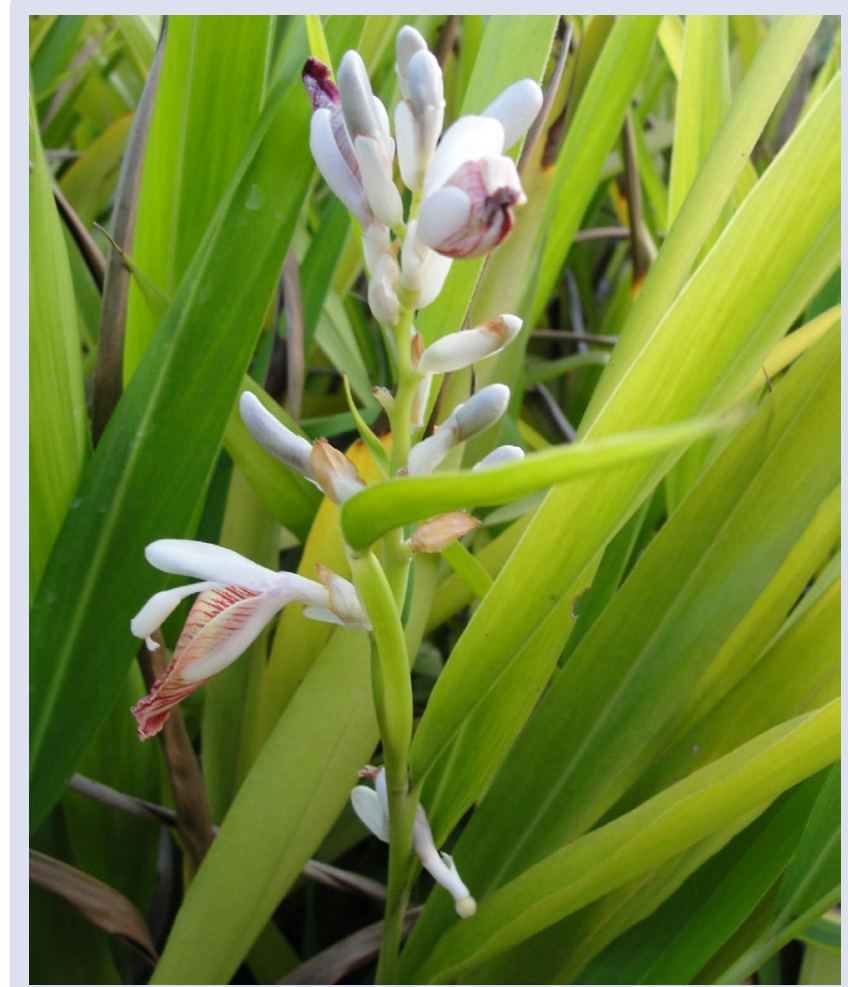

Figure 2: Flower of Alpinia galanga (L.) Willd. (from: https://images. app.goo.gl/XVNmeSWm7jxx6Ls8A).

forms light-red or pale yellow rhizomes from which large clumps of stalks arise which have small greenish-white flowers (Figure 2) that develop into orange-red fruits. A. galanga is probably native to Indonesia and southern China but is now cultivated for its rhizome in various other south-eastern Asian countries as well as Suriname. The rhizome has an aromatic odor and a pungent and spicy taste comparable to that of the common ginger Z. officinale, and is used - either fresh or dried, or powdered or sliced - as a flavoring in many Indonesian, Chinese, Thai, Indian, and Surinamese dishes. The flowers, flower buds, fruits, and young shoots have a flavor reminiscent of cardamom and are also edible. The rhizome essential oil is used to confer an aroma of pine needles to liqueurs such as Chartreuse and Angostura and certain soft drinks, and for preparing Essence d'Amali that is widely used in the perfume industry. ${ }^{38}$

Preparations from fresh or dried A. galanga rhizomes have a wide range of traditional applications. These substances are used, among others, against microbial infections including opportunistic (fungal) infections such as those occurring in AIDS patients, HIV infection, parasitic infections, rheumatic disorders, and gastrointestinal ailments. ${ }^{14,39,40}$ Furthermore, the dried rhizome is the most important raw material in the worldwide renowned topical over-the-counter Chinese pain reliever Tiger balm as well as other traditional Chinese remedies. ${ }^{41}$ And in African-American hoodoo folk magic, A. galanga rhizome is known as 'Little John to chew', 'Chewing John', and the 'lucky court case root', as it would bring luck in court cases and legal matters when it is chewed on and the juice is spit on the floor of the courthouse. ${ }^{42}$

Some of A. galanga's traditional uses may be attributed to the presence in the rhizome of various phytochemicals with meaningful pharmacological activities including phenylpropanoids such as 1'S'-1'-acetoxychavicol acetate, 1'S-1'-acetoxyeugenol acetate, and p-hydroxycinnamaldehyde; terpenes and terpenoids such as $\beta$-pinene, camphor, and eugenol; as well as flavonoids such as galangin and

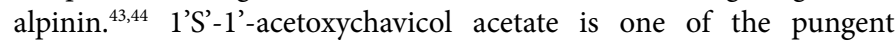


ingredients of the rhizome ${ }^{38}$ while some of the terpenoids are ingredients of the volatile rhizome essential oil and contribute to the taste of the rhizome. ${ }^{45}$

The use of $A$. galanga against microbial infections is supported by the activity of the rhizome essential oil and several organic rhizome extracts against a variety of bacterial species including common food borne bacteria ${ }^{46,47}$ as well as a number of fungi. ${ }^{46,48}$ These effects have been ascribed to 1'S'-1'-acetoxychavicol acetate in these preparations. ${ }^{49}$ This compound also inhibited R-plasmid transfer in various multidrugresistant bacteria ${ }^{49}$ and the active removal of drugs from drug-resistant Mycobacterium spp. ${ }^{50}$ For these reasons, 1 'S'-1'-acetoxychavicol acetate may be pursued as a lead compound for developing more efficacious antibacterial antibiotics.

That A. galanga also may be of benefit against HIV infection is based on the blockage of HIV-1 replication in cultured peripheral blood mononuclear cells by 1'S-1'-acetoxychavicol acetate isolated from the rhizomes. ${ }^{51}$ This compound inhibited HIV mRNA translocation to the cytoplasm for translation into viral proteins, and acted synergistically with the reverse transcriptase inhibitor didanosine in halting HIV-1 replication in these cells. ${ }^{51}$ The supposed antiparasitic properties of the plant are supported by the beneficial effects of various phenylpropanoids, terpenoids, and flavonoids in rhizome extracts against malaria in laboratory mice ${ }^{52}$ as well as their substantial in vitro activity against promastigotes of Leishmania (Leishmania) donovani ${ }^{53}$, the causative agent of visceral leishmaniasis.

Support for the traditional use of A. galanga against rheumatic disorders came from the antiinflammatory activities of methanolic and ethanolic rhizome extracts in carrageenan-induced paw edema and pleurisy in laboratory rats. ${ }^{54,55}$ These effects have been attributed to 1 'S-1'-acetoxychavicol acetate and 1'S-1'-acetoxyeugenol acetate which inhibited the release of $\beta$-hexosaminidase (a marker of IgE-mediated degranulation) in cultured RBL-2H3 peripheral blood cells, reduced the production of IgE-mediated tumor necrosis factor (TNF)- $\alpha$ ) and interleukin (IL)- 4 by these cells, and inhibited local anaphylaxis in laboratory mice. ${ }^{56} \mathrm{p}$-Hydroxycinnamaldehyde may contribute to the antiinflammatory activity of $A$. galanga, since an acetone extract enriched with this compound inhibited the release of hyaluronan, sulfated glycosaminoglycans, and metalloproteinase- 2 from primary human chondrocytes challenged with the proinflammatory cytokine IL- $1 \beta .{ }^{57}$

1 'S-1'-acetoxychavicol acetate and 1'S-1'-acetoxyeugenol also reduced the damage in the gastric mucosa of laboratory rats induced by $\mathrm{HCl}$ or aspirin $^{58}$ and were probably also responsible for the inhibitory effects of rhizome and seed extracts on the development of gastric ulcers and gastric mucosal damage produced in the animals by pyloric ligation and hypothermic restraint stress. ${ }^{59}$ These observations may justify the traditional use of $A$. galanga against gastrointestinal conditions. Notably, a crude rhizome extract substantially decreased the number of necrotic cells in the liver of Sprague-Dawley rats treated with paracetamol ${ }^{60}$, suggesting that A. galanga rhizome preparations also possess hepatoprotective proporties.

\section{Curcuma longa L.}

The turmeric or yellow ginger Curcuma longa L. (1753) presumably arose by selection and vegetative propagation of a hybrid between the wild turmeric Curcuma aromatica Salisb. that is native to India, Sri Lanka, and the eastern Himalayas, and other closely related species. As a result, C. longa is not found in the wild and is only known as a domesticated plant. The plant is abundantly cultivated in India (where it is known as 'haldi') and Indonesia (where it is known as 'kunyit'), as well as many other tropical and subtropical regions throughout the world. It is sterile but readily produces new sprouts from branches of its

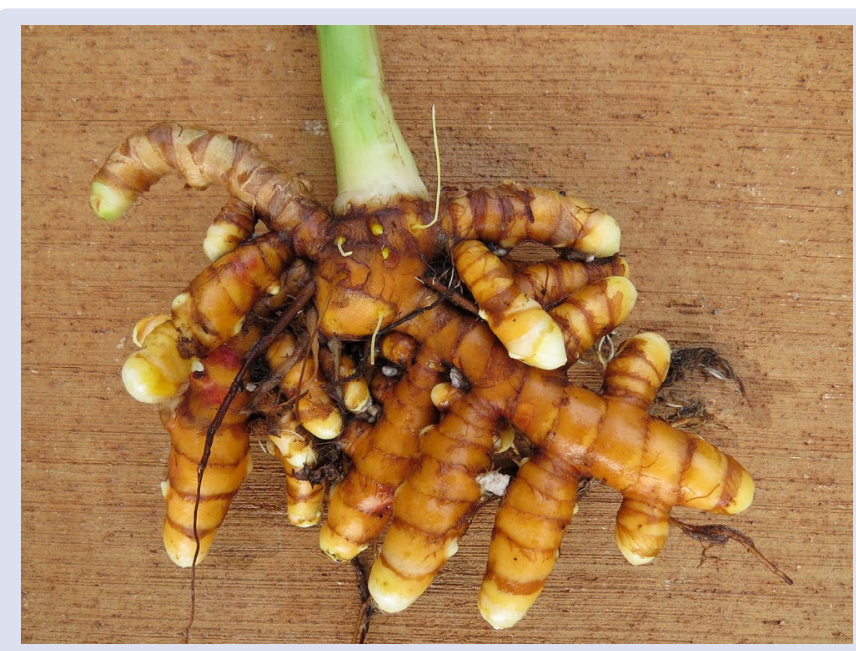

Figure 3: Rhizome of Curcuma longa L. (from: https://images.app.goo.gl/ ZnQgCAFiXVrJHgt8A).

pulpy orange-yellow tuberous underground rhizomes (Figure 3). The maternal plant gives rise to yellow-white flowers which do not produce viable seed.

For human use, the rhizomes are boiled for several hours and then dried in hot ovens, after which they are ground to a deep orange-yellow powder that has a bitter, slightly acrid yet sweet taste. The powder is an essential ingredient of curry, an indispensable spice in many hot, savory, and/or sweet south-eastern Asian and Surinamese-Hindustani dishes. It is also widely used as a coloring agent in cheeses, butters, and mustards, manufactured food products such as canned beverages, dairy products, orange juice, popcorn, sweets, cake icings, cereals, sauces, and gelatins. ${ }^{61}$ The essential oil from the fresh rhizome produced by steam distillation is called turmerol and is incorporated in perfumes to confer a spicy, fresh, and sweet fragrance ${ }^{61}$.

C. longa plays an important role in various social and religious Hindu rituals symbolizing inner purity and pride as well as fertility and prosperity. Thus, the rhizomes are often given as a present to pregnant women. ${ }^{17}$ A paste prepared from fresh rhizomes in coconut oil is applied on the face of the bride and the groom on the the day before the wedding ceremony as part of a purification ritual. ${ }^{17}$ Such a paste is also rubbed on the forehead of newborn babies to protect them from demons and the evil eye and promote their well-being. ${ }^{17}$ As this practice may ward off harmful bacteria ${ }^{62}, C$. longa rhizome resin and essential oil have been incorporated in several sunscreens and facial creams including anti-acne creams. ${ }^{17}$

C. longa rhizome is also extensively used for preparing traditional medicines, particularly in Indian Ayurveda and Unani as well as Indonesian Jawa. These medications are used against a variety of inflammatory conditions such as rheumatoid arthritis, inflammations of the gastrointestinal tract and liver, and eye inflammations, but also for treating precancerous conditions and cancer, various microbial infections, as well as brain disorders such as depression and Alzheimer's disease. ${ }^{15,17,63,64}$ Furthermore, C. longa rhizome is a key ingredient of jamus to promote health and fitness and to enhance mental functioning and well-being. ${ }^{14}$

Important bioactive constituents of $C$. longa rhizome are polyphenolic compounds such as diarylheptanoids (including the yellow-colored curcuminoids such as curcumin which are responsible for the characteristic color and flavor of the rhizome) and diarylpentanoids, as well as terpenoids such as sesquiterpenes, monoterpenes, diterpenes, and triterpenoids. ${ }^{65-67}$ The most common curcuminoid in the plant is curcumin that makes up approximately $90 \%$ of the 
curcuminoid content, as well as its derivatives demethoxycurcumin and bisdemethoxycurcumin. ${ }^{65,66}$ The sesquiterpenes are the main constituents of the rhizome essential oil, while the monoterpenes dominate the essential oils from the leaves and the flowers. ${ }^{66,67}$ The major volatile principles of the rhizome oil are $\alpha$ - and $\beta$-turmerone and aromatic -turmerone. .6,67 $^{6}$

A host of pharmacological studies support the traditional use of $C$. longa preparations as well as curcumin against arthritic conditions (see, for instance, $\left.{ }^{68,69}\right)$. Furthermore, administration of a rhizome extract, the rhizome volatile oil, curcumin itself, natural analogues of curcumin, or semi-synthetic curcumin analogues led to a decrease in carrageeninor formaline-induced rat paw edema as well as cotton pellet-induced granuloma in laboratory rats. ${ }^{70-73}$ The use of curcumin also resulted in a substantial reduction in the inflammatory swelling in rats suffering from arthritis induced by treatment with Freud's adjuvant. ${ }^{72}$ The antiinflammatory effects probably occurred through interference at different levels of the arachidonic acid inflammatory cascade and inhibition of proinflammatory compounds such as prostaglandins, leukotrienes, and COX-2. ${ }^{68,69}$ Of note, a $C$. longa rhizome extract even protected collagen-induced arthritic Sprague-Dawley rats from the degenerative changes in the bone and ankle joints to a comparable extent as betamethasone. ${ }^{74}$ Importantly, clinical trials with curcumin produced encouraging results in patients with rheumatoid arthritis ${ }^{75}$ and postoperative inflammation. ${ }^{76}$

The usefulness of $C$. longa in inflammatory gastrointestinal conditions is sustained by the inhibitory effects of curcumin on the gastric mucosal damage caused by indomethacin in laboratory animals ${ }^{77}$ and on the production of inflammatory cytokines, intercellular adhesion molecule 1 , and TNF- $\alpha$ in the animals. ${ }^{77}$ Furthermore, curcumin substantially improved the profile of inflammatory markers, severity of diarrhea, and colonic architecture in laboratory mice with colitis induced by the laboratory model compound trinitrobenzenesulfonic acid. ${ }^{78}$ Clinical trials indeed showed beneficial effects of curcumin or a standardized $C$. longa rhizome extract in patients with peptic ulcers ${ }^{79}$ or inflammatory bowel disease. ${ }^{80}$ In fact, a Cochrane analysis revealed that curcumin may be a safe and effective therapy for the maintenance of remission in quiescent ulcerative colitis. ${ }^{81}$ In addition, there is some support for the traditional use of $C$. longa against ocular inflammations besides arthritic disease and gastrointestinal inflammations. This is based on the encouraging results of oral curcumin in (a relatively small group of) patients with eye inflammations such as anterior uveitis and idiopathic orbital inflammatory pseudotumors while not producing serious sideeffects. ${ }^{82,83}$

Chronic inflammation is considered an important driving factor for malignant transformation and cancer progression ${ }^{84}$, providing a rationale for using $C$. longa and its curcuminoid constituents as chemopreventive and anticancer compounds. Indeed, comparably to the antiinflammatory effects, the antineoplastic effects would occur through the modulation of critical intracellular signaling pathways such as the NF- $\kappa B$ pathway. ${ }^{85}$ The potential chemopreventive effects of curcumin have been observed in several preclinical models ${ }^{86-88}$ and a few human studies. ${ }^{89-91}$ In addition to reducing the inflammatory cancer microenvironment, these effects might be due to the promotion of apoptosis, inhibition of survival signals, and scavenging of reactive oxidative species. $^{92}$

Other potentially interesting pharmacological activities of C. longa and its constituents that give credence to the traditional claims are antimicrobial, antiparasitic, and anti-Alzheimer effects. The antimicrobial properties have been observed in various standard bacterial strains ${ }^{62,93,94}$ including common periopathogens ${ }^{95}$ and may account for the inclusion of $C$. longa rhizome in jamus for treating inflamed gums, abscesses, menstrual pains, and skin rash $^{7}$ as well as the application of a C. longa-based Javanese ointment called bobok for alleviating the discomfort of, among others, toothache. Furthermore, the broad antiparasitic activity of curcumin ${ }^{96}$ may explain the Surinamese-Javanese custom of including C. longa rhizome in preparations for treating pinworm infections in children.?

The potential usefulness of $C$. longa preparations against neurodegenerative disorders is supported by their capacity to reduce the deposition of plaques similar to those of Alzheimer's disease in the brains of aged mice and the oxidative damage and amyloid pathology in transgenic mouse models of Alzheimer's disease ${ }^{97}$, as well as that of curcumin and dimethoxycurcumin to lessen lead-induced memory deficits in rats. ${ }^{98}$ Although the evidence supporting the efficacy of curcumin in Alzheimer's disease is currently insufficient, the data thus far available are sufficiently encouraging to justify further efforts to optimize absorption, bioavailability, and the timing and length of intervention of the treatment. ${ }^{99}$

\section{Hedychium coronarium J. König}

The white ginger, butterfly ginger lily, or white butterfly ginger Hedychium coronarium J. König, in Suriname also known as 'gember lelie' (Dutch for 'ginger lily'), is native to southern China, Taiwan, Myanmar, northeast India, and Nepal. It may have been brought to South America and the Caribbean by enslaved Africans who used the leaves of this plant as mattresses during their trans-Atlantic journey. ${ }^{100}$ The vernacular name '(white) butterfly ginger' refers to the shape of the flowers which resembles a flying butterfly (Figure 4). This is also reflected by its vernacular name 'flor de mariposa' (Spanish for 'butterfly flower') in Cuba, where it has become the national flower. However, $H$. coronarium has been declared an invasive herb in several parts of Africa and the Americas. ${ }^{101}$ Its rapid vegetative reproduction through underground spread of the rhizomes makes it difficult to control its expansion. ${ }^{101}$ Notwithstanding, the considerable demand of this plant for preparing Ayurvedic medicines has led to such an extent of overharvesting that it has become an endangered species in certain parts of India. ${ }^{102}$

Fortunately, $H$. coronarium is cultivated in many tropical and subtropical countries as an ornamental garden plant and as a source for flower garlands and cut flowers. The essential oil of the flowers has a scent reminiscent of jasmine and is often incorporated in commercial cosmetic preparations such as perfumes, skin conditioners, and facial masks. The juice from the mature seeds is used as a hair and skin treatment by native Hawaiians. ${ }^{100}$ Both the flowers and the rhizomes are consumed as vegetables in parts of south-eastern Asia. The dried stem

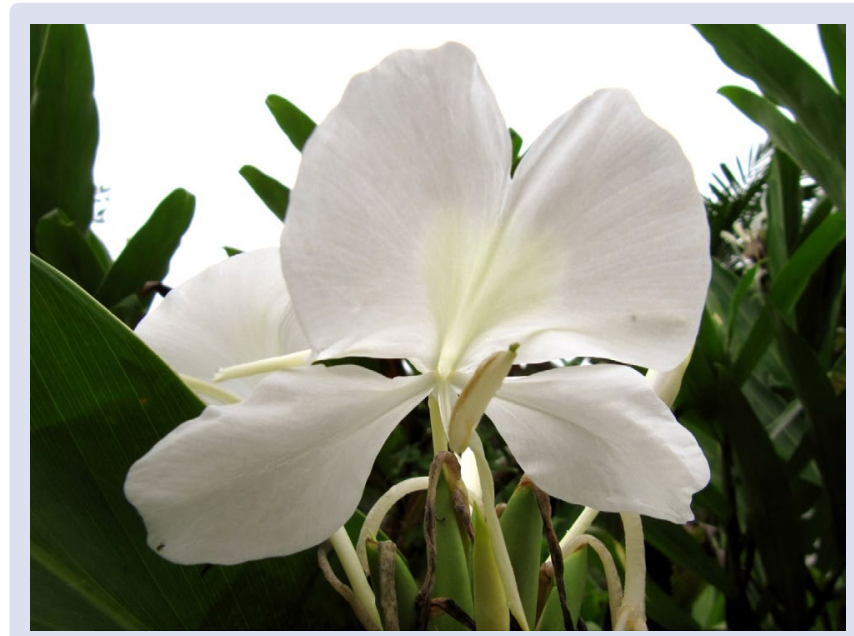

Figure 4: Flower of Hedychium coronarium J. König (from: https:// images.app.goo.gl/xKuFp1A6ZnpZYVFS6). 
contains 43 to $48 \%$ cellulose, making it a useful source of raw material for making paper. ${ }^{103}$

H. coronarium is also medicinally used in various traditional systems throughout the world. Preparations from virtually all its parts are used for treating, among others, microbial infections, parasitic infections, inflammatory complaints such as stiff and sore joints along with pain from rheumatism and arthritis, as well as cancer. ${ }^{104,105}$ The typical scent of the flower is for an important part determined by the terpenes $\beta$-transocimenone, $\alpha$-farnesene, linalool, 1,8-cineole, and $\alpha$-terpineol in the essential oil. ${ }^{106}$ Important phytochemicals in the (essential oils from the) rhizomes and leaves are the large array of biologically active labdane diterpenes such as coronains, coronarins, hedychilactones, and hedychenones, ${ }^{107}$ farnesane sesquiterpenes such as nerolidol and hedychiols, ${ }^{108}$ as well as the monoterpenes 1,8 -cineole, $\beta$-pinene, myrcene, limonene, and benzoyl eugenol. ${ }^{109}$

Pharmacological evidence for antimicrobial activity of $H$. coronarium came from the broad antibacterial and antifungal effects of the rhizome essential oil, extracts from the rhizomes, preparations from the leaves, and decoctions from the flowers. ${ }^{10-113}$ The antimicrobial activities have been ascribed to various terpenoids in the essential oils ${ }^{110,112}$ Of note, the sesquiterpenoid coronarin $\mathrm{D}$ isolated from the rhizomes also showed considerable antibacterial and antifungal effects. ${ }^{113-115}$ In some cases, the antifungal activity was comparable to that of standard drugs such as nystatin and griseofulvin. ${ }^{113,114}$

Furthermore, the rhizome essential oil displayed remarkable activity against earthworms and tapeworms ${ }^{115}$; an ethanolic rhizome extract was active against cultured amastigotes from $L$. (L.) amazonensis (Trypanosomatidae) ${ }^{116}$ and a chloroquine-resistant strain of Plasmodium falciparum $^{116}$; and leaf and rhizome essential oils exerted mosquito larvicidal activities. ${ }^{112}$ These effects have partially been attributed to $\alpha$-pinene, $\beta$-pinene, and 1,8-cineol ${ }^{112}$, and support the traditional use of $H$. coronarium against parasitic infections.

Indications for antiinflammatory and analgesic activity of $H$. coronarium were provided by the inhibitory effects of rhizome (essential oil) preparations on the activities of 5-lipoxygenase and proinflammatory cytokines in vitro ${ }^{117}$, as well as on carrageenan-induced paw edema, heat- or acetic acid-induced writhing, and elongation of tail flick time in laboratory mice. ${ }^{118,119}$ Furthermore, treatment of laboratory mice with a methanolic rhizome extract led to suppression of their motor activity and exploratory behavior, suggesting that central mechanisms of pain perception had been depressed. ${ }^{120}$ These effects have been associated with labdabe diterpenes and farnesane-type sesquiterpenes in the preparations. ${ }^{108,117,119}$.

Potential anticancer activity of $H$. coronarium is supported by the cytotoxicity of a partially purified rhizome extract against brine shrimp nauplii ${ }^{111}$, as well as that of several coronarins and their derivatives isolated from the rhizome against cultured human and animal cancer cell lines. ${ }^{121-123}$ Interestingly, some of the diterpenes substantially inhibited the growth of cultured human umbilical vein endothelial cells, suggesting that they may possess meaningful anti-angiogenic properties. ${ }^{122}$ The cell growth inhibitory effects were in some cases accompanied by cell cycle arrest at the $G_{1}$ phase and signs of apoptosis. ${ }^{123}$ In addition, several coronarin labdane diterpenes as well as benzoyl eugenol showed meaningful cancer chemopreventive activity in in vitro assays, inhibiting NF- $\kappa \mathrm{B}, \mathrm{COX}-1$ and COX-2 activities, the induction of antioxidant response element, and cell proliferation. ${ }^{124}$

\section{Kaempferia galanga (L.) Willd}

The east-Indian galangal, sand ginger, aromatic ginger, or kentyur Kaempferia galanga (L.) Willd. is a small, stemless herb that grows from a rhizomatous rootstock, and is characterized by the thick, rounded leaves that lay flat in a rosette on the ground. The plant develops beautiful

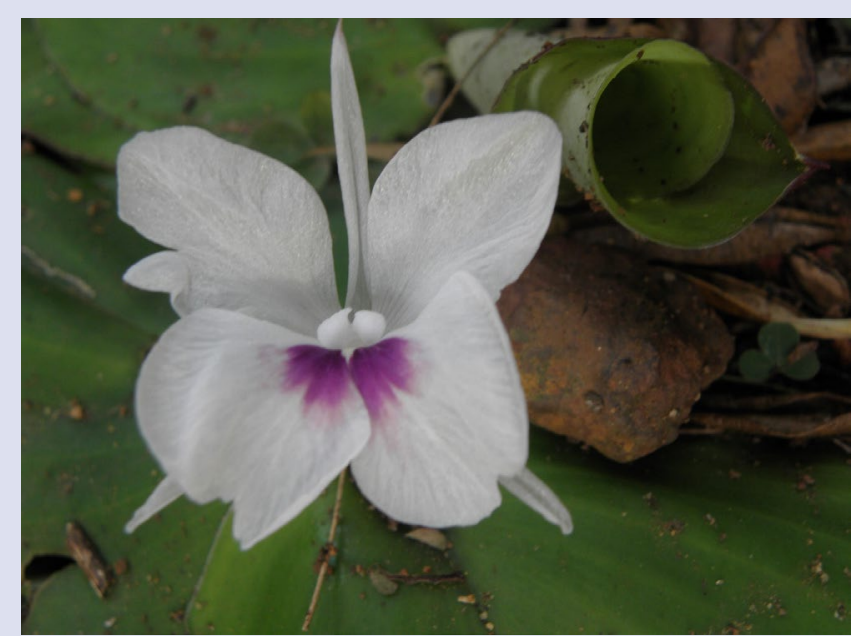

Figure 5: Flower of Kaempferia galanga (L.) willd. (from: https://images. app.goo.gl/o9A3tx2YGBDJoxji9).

white flowers with an amethyst heart which have some resemblance to orchids (Figure 5) and is widely grown as an ornamental in tropical gardens. $K$. galanga is probably native to India but may have originated from Myanmar. It is cultivated for its rhizome in southern China, India, Bangladesh, Thailand, Cambodia, Vietnam, as well as Suriname, but is in general gathered from the wild for local use as a food and medicine. As a result, $K$. galanga has become a highly priced but endangered species in India. ${ }^{125}$

The rhizome has a slightly pungent fragrance with a spicy aroma that resembles that of ginger and is a vital spice in oriental cuisine that contributes to the unique taste and flavor of many Indonesian, Malaysian, Thai, and Surinamese-Javanese dishes. The rhizome is also used as a condiment and, when dried, as a substitute for turmeric in curry powder. The young rhizomes and the young leaves are eaten raw, steamed, in curries or cooked with chilli paste and served as a side dish with rice. The crushed aromatic leaves are also used as a perfume in washing hair. ${ }^{126,127}$ The essential oil extracted from the rhizome is used in perfumery. ${ }^{126,127}$ and the powdered root is added to body powders and cosmetics ${ }^{126,127}$ but also to repel moths in wardrobes. ${ }^{126,127}$

In addition, $K$. galanga has many traditional medical uses. Preparations from particularly the rhizome are used against, among others, colds, sore throat, coughing, bronchitis, asthma, rheumatism and several other microbial infections and inflammatory conditions; various parasitic infections including helminthiasis and malaria; headaches, mouth ulcers, and toothaches; skin problems such as dandruff, leprosy, and psoriasis; as well as restlessness, stress, anxiety, and depression. ${ }^{126-128}$ Interestingly, Surinamese Javanese apply a $K$. galanga-based preparation on the skin of babies to remove excessive body hair; however, at a later age the child also does not develop hair on arms and legs. ${ }^{14}$

The main pharmacologically active ingredients of $K$. galanga probably are phenylpropanoids such as ethyl p-methoxy cinnamate, p-methoxycinnamic acid, ethyl cinnamate, and cinnamaldehyde; flavonols such as kaempferol and kaempferide; as well as a number of terpenoids such as 1,8-cineole, g-careen, and borneole. ${ }^{129,130}$ These compounds are constituents of the rhizome essential oil and have been associated with various pharmacological activities, supporting some of the traditional uses. ${ }^{127,128}$ Leaves and flowers of the plant also contain a number of flavonoids with biological activity. ${ }^{130}$

That $K$. galanga may possess antimicrobial activity is supported by the inhibitory effects of extracts from its rhizome and leaves on the growth of a variety of pathogenic bacterial and fungal species. ${ }^{131-133}$ 
including that of Lactobacillus acidophilus, the bacterium responsible for dental caries. ${ }^{134}$ The antimicrobial activity might be attributed to ethyl p-methoxy cinnamate that showed meaningful antibacterial activity against the skin bacteria Staphylococcus aureus, Staphylococcus epidermidis, and Cutibacterium acnes without causing allergic irritation. ${ }^{135}$ These findings may account for the above-mentioned traditional use of $K$. galanga preparations against mouth ulcers and skin conditions.

Several lines of evidence support pesticidal, larvicidal, and mosquitorepellent activities of $K$. galanga. Methanolic leaf and rhizome extracts as well as the rhizome essential oil elicited considerable repellent and larvicidal activity against harmful mosquito vectors such as Aedes spp., Anopheles spp., Armigeres subalbatus, Culex spp., and Mansonia uniformis, ${ }^{136-138}$ including those resistant to the household insecticide pyrethroid. ${ }^{139}$ These mosquito strains are the carriers and transmitters of serious diseases ranging from yellow fever and chikungunya to malaria and filariasis. Furthermore, the rhizome essential oil displayed strong contact toxicity against the booklouse Liposcelis bostrychophila ,${ }^{140}$ and a rhizome extract showed anthelmintic activity against the Bangladeshi earthworm Pheretima posthuma and insecticidal activity against the rice weevil Sitophilus oryzae. ${ }^{141}$ Notably, neither a crude $K$. galanga rhizome extract nor the rhizome essential oil produced signs of dermal irritation, ${ }^{142}$ providing further support for the usefulness of this plant against dermatological problems. The larvicidal and mosquitorepellent properties of $K$. galanga may particularly be attributable to ethyl p-methoxycinnamate, but also to other phenylpropanoids and/or terpenoids and/or kaempferol 139,140,142,143

Indications for antinociceptive and antiinflammatory activities of $K$. galanga came from the substantial inhibitory effects of an aqueous leaf extract and an alcoholic rhizome extract in abdominal constriction, tail flick, hot plate, and/or formalin assays as well as carrageenan and/ or cotton pellet granuloma models. ${ }^{144-146}$ Markedly, in a double-blind randomized clinical trial with patients suffering from osteoarthritis of the knee, the rhizome extract exerted the same effect on pain, stiffness, and physical interference as the nonsteroidal antiinflammatory drug meloxicam. ${ }^{147}$ The analgesic effects probably occurred through both central components related to opioid receptors and peripheral components associated with the COX pathway. ${ }^{145}$ The antiinflammatory effects probably involved the suppression of IL-1, TNF- $\alpha$, as well as angiogenesis-related events. ${ }^{130,147}$ Both effects were probably caused, at least partially, by ethyl-p-methoxycinnamate. ${ }^{148}$ Together, these observations support the traditional use of $K$. galanga leaves and rhizomes for treating mouth ulcers, headaches, sore throat, swellings, stomach ache, toothache, and rheumatism.

Importantly, $K$. galanga may also possess meaningful sedative properties. This can be derived from the considerable decrease in locomotor activity, onset and duration of thiopental sodium-induced sleeping time, and/or exploratory activities of Swiss mice which had received an extract of the rhizome and/or leaf by inhalation or per $o s .{ }^{149,150}$ The apparent central nervous system-depressant properties of the plant have been attributed to ethyl trans-p-methoxycinamate and ethyl-cinnamate. ${ }^{149}$ These findings support the traditional use of the plant against anxiety and depression, as well as its use in aromatherapy in Japan against sleeplessness and stress and as an ingredient of pain relief Ayurvedic massage blends. ${ }^{149}$

\section{Renealmia alpinia (Rottb.) Maas}

The inkplant, bigi masusa, or blaka masusa Renealmia alpinia (Rottb.) Maas, also known as Renealmia exaltata L. fil.), bears fruits that are red when immature and turn purple-black when mature (Figure 6), and then contain numerous seeds embedded in a yellow pulp. It grows from red, aromatic rhizomes and often forms large colonies. The vernacular name 'inkplant' reflects the previous use of the dark-colored sap of the

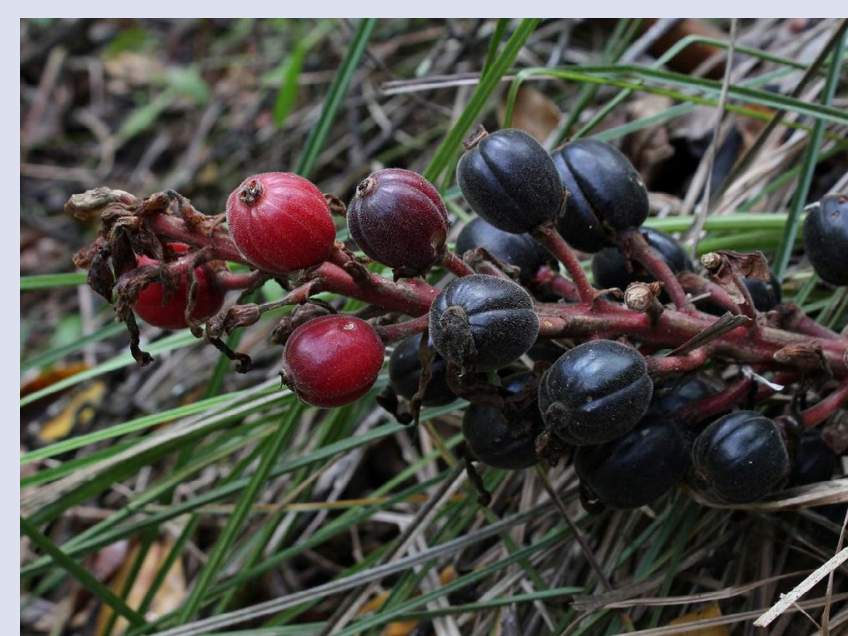

Figure 6: Fruits from Renealmia alpinia (Rottb.) Maas (from: https:// images.app.goo.gl/qZF2bk1icRpYip3R8).

peels from the ripe fruits as an ink for writing and applying skin tattoos ${ }^{151}$ Reddish-colored ink was obtained by adding lime juice to the sap. ${ }^{151} R$. alpinia is native to tropical America and can be found from Mexico to Brazil and in several Caribbean islands. In Suriname, it grows wild in secondary forests and on river banks, but it is cultivated for the redbrown oil from the pulp around the seeds that is used for preparing the widely appreciated tasty Creole rice dish 'masusa moksi aleysi' (literally 'masusa mixed rice'). Peasants from the interior of Brazil often drink a juice prepared from the leaves as a cooling beverage in hot weather. And in Mexico, tamales and empanadas are given a special spicy taste by steaming them while wrapped in fresh $R$. alpinia leaves.

$R$. alpinia is also an important plant in various traditional medical systems. Preparations from the rhizomes and leaves are used against the symptoms of snake bites and scorpion stings in humans and (hunting) dogs; bacterial infections causing fever, gastrointestinal problems, or heart problems manifesting as shortness of breath or chest colds; fungal infections including those causing dandruff and vaginitis; and convulsions during, for instance, epileptic seizures. ${ }^{15,152-154}$ In Suriname, particularly Maroons use preparations from R. alpinia leaves or rhizomes - either alone or together with parts from other plants as a blood-purifying agent, against infertility in women, to speed up delivery, and to prevent uterine inflammation after childbirth and to quickly obtain a slim figure after pregnancy. ${ }^{15}$ Parts of the plant are also included into herbal baths for strengthening the nerves, to convey spiritual strength and self-confidence, to remove sadness, despair, and depression, for protection from the evil eye, and to dispel the spirit of a deceased person. ${ }^{13}$ Curiously, according to ancient Amerindian belief, women should avoid holding R. alpinia fruits too long in their hands as this would accelerate aging. ${ }^{15}$

The characteristic flavor and fragrance of $R$. alpinia seed oil is attributable to monoterpenes such as $\beta$-pinene, limonene, and $\beta$-phellandrene, as well as $\beta$-carotene, labdane diterpenoids, and diarylheptanoids. ${ }^{155}$ Other important phytochemicals in the rhizomes and the leaves are biologically active phenolic compounds such as coumarins and the flavanone pinostrobin, several labdane diterpenes, as well as the kavalactone desmethoxyyangonin. ${ }^{155-158}$

The coumarins and pinostrobin have been associated with the meaningful antivenom properties of $R$. Alpinia. ${ }^{159,160}$ This has been inferred from the substantial analgesic, antiedematous, antihemorrhagic, antidefibrinating, anticoagulant, and neutralizing effects of rhizome and leaf extracts containing these compounds in laboratory mice poisoned with $B$. atrox venom. ${ }^{152,159,160}$ Furthermore, pinostrobin (the 
main ingredient of a dichloromethane leaf extract) elicited strong in vitro analgesic, antinociceptive, and antiinflammatory activities while inhibiting the local tissue damage caused by the hemorrhagic effects of the viper venom. ${ }^{161}$ Pinostrobin may neutralize the effects of snake bites by opposing the anticoagulant and membrane-damaging effects of phospholipase A2 activity in the venom. ${ }^{162}$

The use of $R$. alpinia against microbial infections is supported by the bactericidal activity of leaf and stem extracts against Bacillus subtilis ${ }^{163}$ and the fungicidal activity of rhizome extracts against several species of Candida, the dermatophytic fungus Trichophyton rubrum, and two varieties of the encapsulated yeast Cryptococcus neoformans. ${ }^{164,165}$ These activities have been attributed to several labdane diterpenoids in the extracts. ${ }^{163-165}$ These compounds have also been implicated in the antileishmanial activity against cultured amastigotes of Leishmania (Leishmania) chagasi and L. (L.) amazonensis; ;16,165 the antiprotozoal activity against epimastigotes of Trypanosoma cruzi, the causative agent of Chagas' disease; ${ }^{165}$ the antimalarial activity against a chloroquineresistant strain of $P$. falciparum; ${ }^{116}$ and the cytotoxic effects against several cancer cell lines. ${ }^{156,166}$

Desmethoxyyangonin was previously isolated from the kava-kava plant Piper methysticum ${ }^{167}$ and reversibly inhibited monoamine oxidase (MAO) B in the central nervous system, thereby increasing serotonin and dopamine levels. ${ }^{168}$ Desmethoxyyangonin purified from the dichloromethane extract of $R$. alpinia leaves also potently inhibited recombinant human MAOs - particularly MAO B - in an in vitro study ${ }^{169}$ Thus, this compound may not only suppress anxiety, stimulate feelings of well-being, and promote attention, ${ }^{170}$ but also counter neurological diseases associated with errors in MAOs such as neurodegenerative disturbances ${ }^{171}$ and seizures, ${ }^{172}$ supporting the traditional use of $R$. alpinia preparations for treating seizures in children and other childhood conditions. ${ }^{151}$

\section{Zingiber officinale Roscoe.}

The common ginger or dyindya Z. officinale probably originates from south-eastern Asia where it was presumably domesticated (it does not exist anymore in its wild state), and subsequently spread throughout the rest of the continent and many other parts of the world. It may have been introduced in Suriname by enslaved Africans and Javanese indentured laborers via Western Africa and south-eastern Asia, respectively. ${ }^{10,14}$ The inflorescences directly arise from the rhizome on separate shoots (Figure 7) and bear clusters of white and pink flower buds that bloom into yellow flowers. Because of its esthetic appeal, the plant is often used

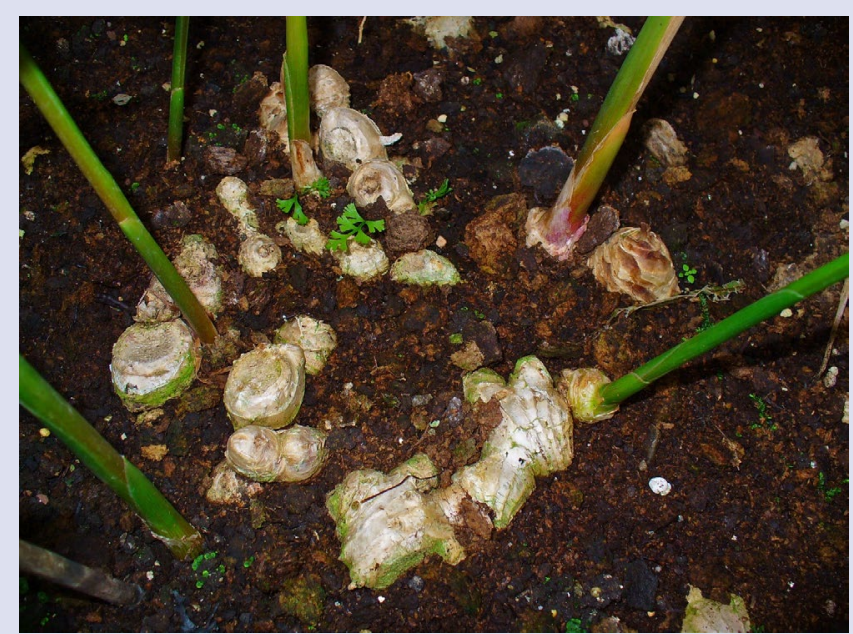

Figure 7: Rhizome of Zingiber officinale Roscoe (from: https://images. app.goo.gl/5DDiHrm1zRP5NzyF7). as landscaping around tropical and subtropical homes. However, $Z$. officinale is mainly cultivated for its rhizome which was one of the first spices exported from Asia to Europe during the spice trade, i.e., before the beginning of the Christian era, and was already highly appreciated by the ancient Greeks and Romans. ${ }^{173}$

Z. officinale has remained an economically valuable crop. In 2018, approximately 3.3 million tonnes were produced worldwide, representing a market revenue of U\$ 5.3 billion. ${ }^{174}$ China dominated the exports in that year, accounting for 390 kilotonnes or more than twothirds of total exports, distantly followed by Thailand (54 kilotonnes), Peru (21 kilotonnes), India (21 kilotonnes), Brazil (15 kilotonnes), and The Netherlands (13 kilotonnes). ${ }^{174}$

The fresh or dried rhizomes are widely used as a hot, fragrant kitchen spice in many South Asian, Latin American, and Caribbean cuisines for flavoring seafood, meat, and vegetarian dishes and for making curries and other spicy dishes. Both the fresh and the dried rhizome are used for these purposes, but the latter is about twice as pungent as the former. The young rhizomes are juicy and fleshy and have a mild taste and are also pickled in vinegar or sherry as a snack, and included in gingerbread, ginger cake, cookies, and speculaas, a spiced shortcrust biscuit that is traditionally baked in The Netherlands and Belgium for consumption around St. Nicholas' Day (5 and 6 December, respectively) and in Germany around Christmas.

In addition, the rhizomes can be immersed in boiling water to make ginger herb tea which is sweetened with honey, and they can be made into ginger wine, ginger ale, and ginger beer. The rhizome also contains an essential oil that is used to flavor essences as well as in perfumery. ${ }^{175}$ The young inflorescences can be eaten raw, and the young, slightly spicy leaves and young shoots can be eaten as a vegetable or pureed and added to sauces and dips. The leaves can also be used to wrap food while it is cooked, adding extra flavor to the food.

Z. officinale has a myriad of applications in various traditional medical systems. In India, it is regarded as a universal medicine ${ }^{176}$ and preparations from the rhizome are ingredients of numerous prescriptions in Ayurvedic and traditional Chinese medicine. ${ }^{176,177}$ These products are internally used to control nausea and vomiting including those caused by morning and motion sickness; microbial infections of the upper respiratory tract; parasitic infections such as filariasis; inflammatory conditions such as asthma as well as rheumatoid arthritis and osteoarthritis; problems with the peripheral circulation including hypertension; and externally to treat spasmodic pain, rheumatism, pain in the muscles and joints of the lower back, menstrual cramps, and sprains. ${ }^{176-178}$

The distinctive odor and flavor of $Z$. officinale rhizome mostly result from volatile oils but also from some nonvolatile phenolic compounds. ${ }^{179}$ The volatile oils account for 1 to $3 \%$ of the weight of fresh rhizome and mainly consist of sequiterpene hydrocarbons, predominantly zingiberol. ${ }^{179}$ The nonvolatile phenolic phytochemicals consist of gingerols, shogaols, paradols, and zingerone, as well as various other gingerol-related compounds ${ }^{179,180}$ The major pungent compound and the best studied phytochemical in $Z$. officinale is 6-gingerol. ${ }^{179,180}$ Zingerone is produced from gingerols during drying and is less pungent. ${ }^{179-181}$ Shagoals are about twice more pungent when compared to the gingerols and and are not found in raw ginger but are the dehydrated products of gingerols that are formed during drying, heating, or prolonged storage of the rhizome. ${ }^{179-181}$

Support for the traditional use $Z$. officinale against nausea and vomiting is provided by initial animal studies suggesting that preparations from the rhizome had antiemetic activity in nausea caused by cyclophosphamide or cisplatin. ${ }^{182-184}$ These effects would occur peripherally, within the gastrointestinal tract, by 
increasing gastric tone and motility through anticholinenergic and antiserotonergic mechanisms. ${ }^{185}$ However, human studies have not led to conclusive results, some speaking in favor of antiemetic properties of $Z$. officinale (see, for instance, ${ }^{186}$ ) but others contradicting these actions (see, for instance, ${ }^{187}$ ). On the other hand, various gingerols, 6-shogaol, and zingerone were shown to antagonize the activation of cholinergic and serotonin receptors in laboratory models, ${ }^{188,189}$ the main targets of emetogenic chemotherapeutic drugs. Furthermore, a few reviews and meta-analyses concluded that $Z$. officinale was better than placebo in pregnancy-related nausea and vomiting as well as nausea and vomiting induced by chemotherapy or motion sickness but that this should be verified in sufficiently large clinical studies (see, for instance, ${ }^{190}$ ).

Indications for the usefulness of $Z$. officinale against microbial infections came from the broad in vitro antibacterial and antifungal activity of organic extracts from the rhizome. ${ }^{191,192}$ These effects might be associated with the flavonoid fractions of the extracts. ${ }^{193}$ Various lines of evidence also support the usefulness of the plant against parasitic infections. Thus, 6-gingerol, 10-gingerol, 6-shogaol, 10-shogaol, and/ or hexahydrocurcumin isolated from the rhizome elicited larvicidal activity against the yellow fever mosquito Aedes aegypti that carries and spreads yellow fever, dengue fever, chikungunya, and Zika fever viruses, as well as the southern house mosquito Culex quinquefasciatus, the primary vector of the round worm Wuchereria bancrofti that causes lymphatic filariasis. ${ }^{194}$

Furthermore, methanol and aqueous extracts of $Z$. officinale rhizome displayed substantial anthelmintic activity against the barber's pole worm Haemonchus contortus that causes anemia, edema, and eventually death of infected sheep and goats ${ }^{195}$, as well as the Indian earthworm Pheretima posthuma that has been used as a model for intestinal roundworm parasites of humans. ${ }^{196}$ These extracts also elicited meaningful activity against larvae of the rat long worm Angiostrongylus cantonensis as well as those of the parasitic fish nematode Anisakis simplex. ${ }^{197}$ A. cantonensis produces angiostrongyliasis, the most common cause of eosinophilic meningitis or meningoencephalitis in south-eastern Asia and the tropical Pacific islands, and A. simplex is associated with anisakiasis, a gastrointestinal infection characterized by severe abdominal cramps.

The use of $Z$. officinale as an antiinflammatory and analgesic compound is supported by the notable inhibitory effects of a rhizome extract on edema, stretching, as well as jumping and hind paw-licking of laboratory rodents subjected to the carrageenan-induced rat paw oedema test, the acetic acid-induced writhing assay, and the hot plate test. ${ }^{198-200}$ Comparable results were found with several in vitro antiinflammatory assays activity such as protein denaturation inhibition, membrane stabilization, protease inhibition, and anti-lipoxygenase assays. ${ }^{201}$ The in vivo antiinflammatory activity was mainly ssociated with certain paradols, shogaols, and gingerols, and might involve, among others, inhibition of LPS-induced PGE production $^{202}$ and decreases in proinflammatory cytokines and chemokines resulting in inhibition of the activation and migration of monocytes and leukocytes. ${ }^{200}$ These compounds also strongly inhibited COX-2 activity in intact cells. ${ }^{201}$

\section{CONCLUDING REMARKS}

In the current paper, phytochemical and pharmacological evidence have been compiled to support the traditional medical uses of seven common Zingiberacea species in Suriname. The data obtained are summarized in Table 1 and indicate that there is for all plants scientific evidence to support some of the traditional uses. Therefore, there is at least some merit to the broad use of these plants as traditional and alternative medicines and as nutraceuticals, i.e., foods or food constituents that provide health benefits in addition to nutritional value. In addition, drug regulatory authorities such as the FDA generally regard many if not all Zingiberacea species as safe. ${ }^{203}$
Furthermore, almost all the plants possessed antimicrobial and antiparasitic properties which may support their use against (certain) infectious diseases. This is not unexpected when considering the repellent properties of the pungent pharmacologically active constituents in their essential oils. However, the apparent antimicrobial and antiparasitic effects have in general been observed in a handful of preclinical studies. Indeed, clinical proof that any of these compounds elicit these effects is absent, particularly against more serious infectious diseases such as, among others, malaria, chikungunya, filaria, and leishmaniasis. Thus, despite the availability of supporting data, claims of antimicrobial and antiparasitic activities of Zingiberacea species should be taken with caution to avoid the risk of using inefficacious substances and delay in seeking professional help in these cases.

Many of the plants also displayed antiinflammatory and analgesic activity, but again, mostly in studies with laboratory animals. Thus, these data should also be regarded with caution. Still, the results from clinical studies evaluating the efficacy of curcumin from C. longa against rheumatoid arthritis ${ }^{75}$ and that of the rhizome extract from K. galanga against osteoarthritis of the knee ${ }^{147}$ were encouraging. The same holds true for clinical studies on the capacity of curcumin from $C$. longa to improve neurodegenerative diseases such Alzheimer's disease ${ }^{99}$ and that of $Z$. officinale rhizome preparations to control pregnancyrelated, chemotherapy-associated, and motion sickness-related nausea and vomiting. ${ }^{190}$

However, the relatively small size of the patient populations enrolled in the studies as well as other flaws in the study designs have led to serious doubts about the reliability of the outcomes of the trials (see, for instance $\left.\mathrm{e}^{75,76,190}\right)$. Still, the many encouraging preclinical and clinical data warrant re-evaluation of (some of) these substances in sufficiently large and better designed clinical studies. These studies should also take into account that many pharmacologically active compounds of Zingiberacea species are ingredients of volatile oils and thus poorly water-soluble. This may create major pharmcodynamic challenges when administered to humans. For instance, the high lipophilicity of curcumin has led to too low oral bioavailability, chemical stability, and intracellular concentrations to make the results from clinical studies evaluating its anticancer activity reliable. ${ }^{204}$

This has led to attempts to increase the overall anticancer activity of curcumin by introducing structural modifications in the molecule that would improve its selectivity towards cancer cells as well as its bioavailability and/or stability, or to use delivery systems that would improve its physicochemical properties. ${ }^{117}$ The active ingredients from other Zingiberacea species may conceivably also pose such problems which may be solved through comparable strategies. An example is desmethoxyyangonin from $R$. alpinia that may be modified in order to improve its delivery to the brain for treating seizures in children. ${ }^{131}$ These studies may help definitely establish the therapeutic importance of the Zingiberaceae.

\section{REFERENCES}

1. Kress WJ, Prince LM, Williams KJ. The phylogeny and a new classification of the gingers (Zingiberaceae): evidence from molecular data. Am $\mathrm{J}$ Bot. 2002;89:1682-96.

2. George M, Cherian E. Emergent global marketing challenges for Kerala cardamom producers vis-à-vis role of the spice board of India. Int J Comm Develop Manag Stud. 2017;1:39-62.

3. Silva ABWR, Herath $H$, Senanayake SP, Swarnathilaka DBR. Phenetic and genetic characterization of selected economically important species in the family Zingiberaceae. Sri Lankan J Biol. 2018;3:34-43

4. Wohlmuth $\mathrm{H}$. Phytochemistry and pharmacology of plants from the ginger family, Zingiberaceae. PhD thesis, Southern Cross University, Lismore, New South Wales, Australia.

5. General Bureau of Statistics. Demographic data 2013-2016. 2018 https://www. statistics-suriname.org/wp-content/uploads/2019/02/DEMOGRAFISCHEDATA-2013-2016.pdf. 
6. General Bureau of Statistics. Gross domestic product 2014-2018. 2018 https://statistics-suriname.org/wp-content/uploads/2019/09/SURINAME-BBPSCHATTINGEN-2014-2018-Version-2-GDP-ESTIMATES-2014-2018-Version-2. pdf.

7. World Bank Group. Suriname - World Bank: Data 2019 https://data.worldbank. org/country/suriname.

8. Mans DRA, Ganga D, Kartopawiro J. Meeting of the minds: traditional herbal medicine in multiethnic Suriname. Chapter 6. In: El-Shemy H (ed). Aromatic and Medicinal Plants - Back to Nature. InTech, Rijeka, Croatia. 2017.

9. Crosby AW. The Columbian exchange: biological and cultural consequences of 1492. Greenwood Press, Westport (CT), USA.1972.

10. Carney JA. Rice and memory in the age of enslavement: Atlantic passages to Suriname. Slavery Abolition 2005;26:325-47.

11. Mans DRA. Nature, green in leaf and stem. Research on plants with medicinal properties in Suriname. Clin Med Invest 2016;2:1-10.

12. May AF. Sranan oso dresi. Surinaams kruidenboek (Surinamese folk medicine. A collection of Surinamese medicinal herbs). De Walburg Pers, Amsterdam, The Netherlands. 1982

13. Heyde H. Surinaamse medicijnplanten (Surinamese medicinal plants), $2^{\text {nd }}$ ed Westfort, Paramaribo, Suriname. 1987

14. Tjong Ayong G.Het gebruik van medicinale planten door de Javaanse bevolkingsgroep in Suriname (The use of medicinal plants by the Javanese in Suriname). Instituut voor de Opleiding van Leraren, Paramaribo, Suriname.1989.

15. Van Andel TR, Ruysschaert S. Medicinale en rituele planten van Suriname (Medicinal and ritual plants of Suriname). KIT Publishers, Amsterdam, The Netherlands. 2012

16. Moret ES. Trans-Atlantic diaspora ethnobotany: legacies of West African and Iberian Mediterranean migration in Central Cuba. Pp. 217-245. In: Voeks R, Rashford J (eds). African Ethnobotany in the Americas. Springer, New York (NY), USA. 2013.

17. Prasad S, Aggarwal BB. Turmeric, the golden spice: from traditional medicine to modern medicine. Chapter 13. In: Benzie IFF, Wachtel-Galor S (eds). Herbal Medicine: Biomolecular and Clinical Aspects, $2^{\text {nd }}$ edition. CRC Press/Taylor \& Francis, Boca Raton (FL), USA. 2011.

18. Ogbole OO, Ajaiyeoba EO. Traditional management of tuberculosis in Ogun State of Nigeria: the practice and ethnobotanical survey. Afr J Tradit Complement Altern Med. 2009;7:79-84.

19. Gbolade A. Ethnobotanical study of plants used in treating hypertension in Edo State of Nigeria. J. Ethnopharmacol. 2012;144:1-10.

20. Amadi SW, Zhang Y, Wu G. Research progress in phytochemistry and biology of Aframomum species. Pharm Biol. 2016;54:2761-70.

21. Agim CS, Nosiri Cl, Chukwuma A, Okechukwu A. Evaluation of the phytochemical and GC-MS analysis of the aqueous seed extract of Aframomum melegueta. J Pharmacogn Phytochem. 2017;6:101-4.

22. Wabo HK, Tane P, Connolly JD. Diterpenoids and sesquiterpenoids from Aframomum arundinaceum. Biochem Syst Ecol. 2006;34:603-5.

23. Okigbo RN, Ogbonnanya O U. Antifungal effects of two tropical plants extracts Ocimum gratissimum and Afromaomum melegueta on post-harvest yam Discorea spp rot. Afr J Biotechnol. 2006;5:727-31.

24. Djeussi DE, Noumedem JA, Seukep JA, Fankam AG, Voukeng IK. Antibacterial activities of selected edible plants extracts against multidrug-resistant Gramnegative bacteria. BMC Complement Altern Med. 2013;13:164.

25. Ngwoke KG, Chevallier O, Wirkom VK, Stevenson P, Elliott CT. In vitro bactericidal activity of diterpenoids isolated from Aframomum melegueta K.Schum against strains of Escherichia coli, Listeria monocytogenes and Staphylococcus aureus. J Ethnopharmacol. 2014;151:1147-54.

26. Uzeh RE, Oguntosin DO. Efficacy of essential oils from some African spices against two strains of Bacillus cereus isolated from vegetable salad. J Food Res. 2013;2:48-54.

27. Ilic NM, Dey M, Poulev AA, Logendra S, Kuhn PE, Raskin I. Antiinflammatory activity of grains of paradise (Aframomum melegueta Schum) extract. J Agric Food Chem. 2014;62:10452-7.

28. Ukeh DA, Birkett MA, Pickett JA, Bowman AS, Mordue AJ. Repellent activity of alligator pepper, Aframomum melegueta, and ginger, Zingiber officinale, against the maize weevil, Sitophilus zeamais. Phytochemistry. 2009;70:751-58.

29. Escoubas P, Lajide L, Mizutani J. Termite antifeedant activity in Aframomum melegueta. Phytochemistry. 1995;40:1097-9.

30. Dybas CL, Raskin I. Out of Africa: a tale of gorillas, heart disease and a swamp plant. BioScience. 2007;57:392-7.

31. Keum YS, Kim J, Lee KH, Park KK, Surh YJ. Induction of apoptosis and caspase-3 activation by chemopreventive [6]-paradol and structurally related compounds in KB cells. Cancer Lett. 2002;177:41-7.

32. Chung WY, Jung YJ, Surh YJ, Lee SS, Park KK. Antioxidative and antitumor promoting effects of [6]-paradol and its homologs. Mutat Res. 2001;496:19906.
33. Mbongue G, Kamtchouing P, Dimo T. Effects of the aqueous extract of dry seeds of Aframomum melegueta on some parameters of the reproductive function of mature male rats. Andrologia. 2012;44:53-8.

34. Akpanabiatu MI, Ekpo ND, Ufot UF, Udoh NM, Akpan EJ, Etuk EU. Acute toxicity, biochemical and haematological study of Aframomum melegueta seed oil in male Wistar albino rats. J Ethnopharmacol. 2013;150: 590-4.

35. Inegbenebor $U$, Ebomoyi MI, Onyia KA, Amadi K, Aigbiremolen AE. Effect of alligator pepper (Zingiberaceae Aframomum melegueta) on first trimester pregnancy in Sprague Dawley rats. Niger J Physiol Sci. 2009;24:161-4

36. Lawal B, Aderibigbe A, Essiet G, Essien A. Hypotensive and antihypertensive effects of Aframomum melegueta seeds in humans. Int $\mathrm{J}$ Pharmacol. 2007;3:311-8 .

37. Adefegha SA, Oboh G. Inhibition of key enzymes linked to type 2 diabetes and sodium nitroprusside-induced lipid peroxidation in rat pancreas by water extractable phytochemicals from some tropical spices. Pharm Biol. 2012;50:857-65.

38. Yang $X$, Eilerman RG. Pungent principal of Alpinia galanga (L.) Swartz and its applications. J Agric Food Chem. 1999;47:1657-62.

39. Verma RK, Mishra G, Singh P, Jha KK, Khosa RL. Alpinia galanga - an important medicinal plant: a review. Der Pharmacia Sinica. 2011;2:142-54.

40. Shukla D, Jawaid T, Srivastava S. Alpinia galanga: an overview and herbal interactions. Med Res Chron. 2017;4:301-5.

41. Wang S, Zhao $Y$, Zhang J, Huang $X$, Wang Y. Antidiarrheal effect of Alpinia oxyphylla Miq. (Zingiberaceae) in experimental mice and its possible mechanism of action. J Ethnopharmacol. 2015;168:182-90.

42. Yronwode C. Hoodoo herb and root magic. The Lucky Mojo Curio Co. Forestville (CA), USA. 2002.

43. MaX-N, Xie C-L, Miao Z, Yang Q, Yang X-W. An overview of chemical constituents from Alpinia species in the last six decades. RSC Adv. 2007;7:14114-44.

44. Chouni A, Santanu P. A review on phytochemical and pharmacological potential of Alpinia galanga. Pharmacogn J. 2018;10:9-15.

45. De Pooter HL, Omar MN, Coolsaet BA, Schamp NM. The essential oil of greater galanga (Alpinia galanga) from Malaysia. Phytochemistry. 1985;24:93-6.

46. Thuy Quynh VT, Duszkiewicz-Reinhard W. Antimicrobial activity of essential oils from fresh and dried Alpinia galanga rhizomes. J Essent Oil Bear Plants. 2004;7:165-70

47. Rao K, Ch B, Narasu LM, Giri A. Antibacterial activity of Alpinia galanga (L) Willd crude extracts. Appl Biochem Biotechnol. 2010;162:871-84.

48. Janssen AM, Scheffer JJ. Acetoxychavicol acetate, an antifungal component of Alpinia galanga L. Planta Med. 1985;51:507-11.

49. Latha C, Shriram VD, Jahagirdar SS, Dhakephalkar PK, Rojatkar SR. Antiplasmid activity of 1 'S'-1'-acetoxychavicol acetate from Alpinia galanga against multidrug resistant bacteria. J Ethnopharmacol. 2009;123:522-5.

50. Roy SK, Pahwa S, Nandanwar H, Jachak SM. Phenylpropanoids of Alpinia galanga as efflux pump inhibitors in Mycobacterium smegmatis mc2 155 Fitoterapia. 2012;83:1248-55.

51. Ye Y, Li B. 1'S-1'-Acetoxychavicol acetate isolated from Alpinia galanga inhibits human immunodeficiency virus type 1 replication by blocking Rev transport. J Gen Virol. 2016;87:2047-53.

52. Al-Adhroey AH, Nor ZM, Al-Mekhlafi HM, Mahmud R. Median lethal dose, antimalarial activity, phytochemical screening and radical scavenging of methanolic Languas galanga rhizome extract. Molecules. 2010;15:8366-76.

53. Kaur A, Singh R, Dey CS, Sharma SS, Bhutani KK, Singh IP. Antileishmanial phenylpropanoids from Alpinia galanga (Linn.) Willd. Indian J Exp Biol. 2010;48:314-7.

54. Unnisa A, Parveen TD. Anti-inflammatory and acute toxicity studies of the extracts from the rhizomes of Alpinia galangaWilld. Der Pharm Sin. 2011;2:3617.

55. Subash KR, Prakash GB, Reddy KV, Manjunath K, Rao KU. Anti-inflammatory activity of ethanolic extract of Alpinia galanga in carrageenan induced pleurisy rats. Natl J Physiol Pharm Pharmacol. 2016;6:468-70

56. Matsuda $H$, Morikawa T, Managi H, Yoshikawa M. Antiallergic principles from Alpinia galanga: structural requirements of phenylpropanoids for inhibition of degranulation and release of TNF- $\alpha$ and IL-4 in RBL-2H3 cells. Bioorg Med Chem Lett. 2003;13:3197-02.

57. Phitak T, Choocheep K, Pothacharoen P, Pompimon W, Premanode B. The effects of p-hydroxycinnamaldehyde from Alpinia galanga extracts on human chondrocytes. Phytochemistry. 2009;70:237-43.

58. Matsuda H, Pongpiriyadacha $Y$, Morikawa T, Ochi M, Yoshikawa $M$ Gastroprotective effects of phenylpropanoids from the rhizomes of Alpinia galanga in rats: structural requirements and mode of action. Eur J Pharm. 2003;471:59-67.

59. Al-Yahya MA, Rafatullah S, Mossa JS, Ageel AM, Al-Said MS, Tariq M. Gastric antisecretory, antiulcer and cytoprotective properties of ethanolic extract of Alpinia galanga willd in rats. Phyther Res. 1990;4:112-4. 
60. Hemabarathy B, Budin SB, Feizal V. Paracetamol hepatotoxicity in rats treated with crude extract of Alpinia galanga. J Biol Sci. 2009;9:57-62

61. Sharma RA, Gescher AJ, Steward WP. Curcumin: the story so far. Eur J Cancer. 2005;41:1955-68

62. Moghadamtousi SZ, Kadir HA, Hassandarvish P, Tajik H, Abubakar S. A review on antibacterial, antiviral, and antifungal activity of curcumin. Biomed Res Int. 2014:186864.

63. Gupta SC, Sung B, Kim JH, Prasad S, Li S, Aggarwal BB. Multitargeting by turmeric, the golden spice: from kitchen to clinic. Mol Nutr Food Res. 2013;57:1510-28

64. Kunnumakkara B, Bordoloi D, Padmavathi G, Monisha J, Roy NK. Curcumin, the golden nutraceutical: multitargeting for multiple chronic diseases. $\mathrm{Br} J$ Pharmacol. 2017;174:1325-48.

65. Li S, Yuan W, Deng G, Wang P, Yang P. Chemical composition and product quality control of turmeric (Curcuma longa L.). Pharm Crops. 2011;2:28-54.

66. Sabale P, Modi A, Sabale V. Curcuma longa Linn. A phytochemical and phytopharmacological review. Res J Pharmacogn Phytochem. 2013;5:59-68.

67. Stanojević JS, Stanojević LP, Cvetković DJ, Danilović BR. Chemical composition, antioxidant and antimicrobial activity of the turmeric essential oil (Curcuma longa L.). Advan Technol. 2015;4:19-25.

68. Jurenka JS. Anti-inflammatory properties of curcumin, a major constituent of Curcuma longa: a review of preclinical and clinical research. Altern Med Rev. 2009;14:141-53.

69. Tabrizi R, Vakili S, Akbari M, Mirhosseini N, Lankarani KB. The effects of curcumin-containing supplements on biomarkers of inflammation and oxidative stress: a systematic review and meta-analysis of randomized controlled trials. Phytother Res. 2018;33:253-62.

70. Arora RB, Basu N, Kapoor V, Jain AP. Anti-inflammatory studies on Curcuma longa (turmeric). Indian J Med Res. 1971;59:1289-95

71. Chandra D, Gupta SS. Anti-inflammatory and antiarthritic activity of volatile oil of Curcuma longa (haldi). Indian J Med Res. 1972;60:138-42.

72. Srimal RC, Dhawan BN. Pharmacology of diferuloyl methane (curcumin), a nonsteroidal anti-inflammatory agent. J Pharm Pharmacol. 1973;25:447-52.

73. RaoTS, Basu N, Siddiqui HH. Anti-inflammatory activity of curcumin analogues. Indian J Med Res. 1982;75:574-8.

74. Kamarudin TA, Othman F, Mohd Ramli ES, Md Isa N, Das S. Protective effect of curcumin on experimentally induced arthritic rats: detailed histopathological study of the joints and white blood cell count. EXCLI J. 2011;11:226-36.

75. Deodhar SD, Sethi R, Srimal RC. Preliminary study on antirheumatic activity of curcumin (diferuloyl methane). Indian J Med Res. 1980;71:632-43.

76. Satoskar RR, Shah SJ, Shenoy SG. Evaluation of anti-inflammatory property of curcumin in patients with post operative inflammation. Int J Clin Pharmacol Ther Toxicol. 1986;24:651-4.

77. Thong-Ngam D, Choochuai S, Patumraj S, Chayanupatkul M, Klaikeaw N Curcumin prevents indomethacin-induced gastropathy in rats. World $J$ Gastroenterol. 2012;18:1479-84.

78. Ukil A, Maity S, Karmakar S, Datta N, Vedasiromoni JR, Das PK. Curcumin, the major component of food flavour turmeric, reduces mucosal injury in trinitrobenzene sulphonic acidinduced colitis. Br J Pharmacol. 2003;139:20918.

79. Prucksunand C, Indrasukhsri B, Leethochawalit M, Hungspreugs K. Phase I clinical trial on effect of the long turmeric (Curcuma longa Linn) on healing of peptic ulcer. Southeast Asian J Trop Med Public Health. 2011;32:208-15.

80. Hanai H, lida T, Takeuchi K, Watanabe F, Maruyama Y. Curcumin maintenance therapy for ulcerative colitis: randomized, multicenter, double-blind, placebocontrolled trial. Clin Gastroenterol Hepatol. 2006;4:1502-6.

81. Kumar S, Ahuja V, Sankar MJ, Kumar A, Moss AC. Curcumin for maintenance of remission in ulcerative colitis Cochrane Database Syst Rev. 2012;17:CD008424.

82. Lal B, Kapoor AK, Asthana OP, Agrawal PK, Prasad R. Efficacy of curcumin in the management of chronic anterior uveitis. Phytother Res. 1999;13:318-22.

83. 831. Lal B, Kapoor AK, Agrawal PK, Asthana OP, Srimal RC. Role of curcumin in idiopathic inflammatory orbital pseudotumours. Phytother Res. 2000;14:44347.

84. Hanahn D, Weinberg RA. Hallmarks of cancer: the next generation. Cell. 2011;144:646-74.

85. Marquardt JU, Gomez-Quiroz L, Arreguin Camacho LO, Pinna F, Lee YH. Curcumin effectively inhibits oncogenic NF- $\kappa$ B signaling and restrains stemness features in liver cancer. J Hepatol. 2015;63:661-9.

86. Ushida J, Sugie S, Kawabata K, Pham OV, Tanaka T. Chemopreventive effect of curcumin on N-nitrosomethylbenzylamine-induced esophageal carcinogenesis in rats. Jpn J Cancer Res. 2000;91:893-8.

87. Perkins S, Verschoyle RD, Hill K, Parveen I, Threadgill MD. Chemopreventive efficacy and pharmacokinetics of curcumin in the min/+ mouse, a model of familial adenomatous polyposis. Cancer Epidemiol Biomarkers Prev. 2002; $11: 535-40$.
88. Bower M, Aiyer H, Li Y, Martin R. Chemoprotective effects of curcumin in esophageal epithelial cells exposed to bile acids. World J Gastroenterol. $201 ; 16: 4152-8$

89. Kuttan R, Sudheeran PC, Josph C. Turmeric and curcumin as topical agents in cancer therapy. Tumori. 1987;73:29-31.

90. Cruz-Correa M, Shoskes DA, Sanchez P, Zhao R, Hylind LM. Combination treatment with curcumin and quercetin of adenomas in familial adenomatous polyposis. Clin Gastroenterol Hepatol. 2006;4:1035-8.

91. Horie S. Chemoprevention of prostate cancer: soy isoflavones and curcumin Korean J Urol. 2012;53:665-72.

92. Park W, Amin AR, Chen ZG, Shin DM. New perspectives of curcumin in cancer prevention. Cancer Prev Res. 2013;6:387-400.

93. Gunes H, Gulen D, Mutlu R. Antibacterial effects of curcumin: an in vitro minimum inhibitory concentration study. Toxicol Ind Health. 2016;32:246-50.

94. Teow SY, Liew K, Ali SA, Khoo AS, Peh SC. Antibacterial action of curcumin against Staphylococcus aureus: a brief review. JTrop Med. 2016;2016:2853045.

95. Bomdya RS, Shah MU, Doshi YS, Shah VA, Khirade SP. Antibacterial activity of curcumin (turmeric) against periopathogens - An in vitro evaluation. J Adv Clin Res Insights. 2017;4:175-80.

96. Cheraghipour K, Marzban A, Ezatpour B, Khanizadeh S, Koshki J. Antiparasitic properties of curcumin: a review. AIMS Agriculture and Food. 2019;4:1-18.

97. Rao R, Descamps O, John V, Bredesen DE. Ayurvedic medicinal plants for Alzheimer's disease: a review. Alzheimer's Res Ther. 2012;4(3):22.

98. Dairam A, Limson JL, Walkins GM, Antunes E, Daya S. Curcuminoids, curcumin, and demethoxycurcumin reduce lead-induced memory deficits in male Wistar rats. J Agric Food Chem. 2007;55:1039-44.

99. Goozee KG, Shah TM, Sohrabi HR, Rainey-Smith SR, Brown B. Examining the potential clinical value of curcumin in the prevention and diagnosis of Alzheimer's disease. Br J Nutr. 2016;115:449-65.

100. De Souza JA, Correia MCR. Biologia floral de Hedychium coronarium Koen. (Zingiberaceae). (Floral biology of Hedychium coronarium Koen. (Zingiberaceae)). (Rev Bras Horticult Ornament. 2007;13:21-30.

101. Meyer JY. Preliminary review of the invasive plants in the Pacific islands (SPREP Member Countries). Pp. 85-114. In Sherley G (ed). Invasive species in the Pacific: a technical review and draft regional strategy. South Pacific Regional Environment Programme, Apia, Samoa. 2012.

102. Manish M. Current status of endangered medicinal plant Hedychium coronarium and causes of population decline in the natural forests of Anuppur and Dindori districts of Madhya Pradesh, India. Int Res J Bio Sci. 2013;2:1-6.

103. Bisht NS, Bhandari S. In vitro plant regeneration from seedling explants of Hedychium coronarium J. Koenig. J Med Plants Res. 2012;6:5546-51.

104. Pachurekar P, Dixit AK. A review on pharmacognostical, phytochemical and ethnomedicinal properties of Hedychium coronarium J. Koenig an endangered medicine. Int J Chin Med. 2017;1:49-61.

105. Ray S, Sheikh M, Mishra S. Ethnomedicinal plants used by tribal of East Nimar region, Madhya Pradesh. Indian J Trad Knowl. 2011;10:367-71.

106. Báez D, Pino JA, Morales D. Floral scent composition in Hedychium coronarium J. Koenig analyzed by SPME. J Essent Oil Res. 2011;23:64-7.

107. Chimnoi N, Pisutjaroenpong S, Ngiwsara L, Dechtrirut D, Chokchaichamnankit D. Labdane diterpenes from the rhizomes of Hedychium coronarium. Nat Prod Res. 2008;22:1249-56

108. Morikawa T, Matsuda H, Sakamoto Y, Ueda K, Yoshikawa M. New farnesanetype sesquiterpenes, hedychiols a and b 8,9-diacetate, and inhibitors of degranulation in RBL-2H3 cells from the rhizome of Hedychium coronarium. Chem Pharm Bull (Tokyo). 2002;50:1045-9.

109. Dos Santos BCB, Barata LES, Marques FA, Baroni ACM, Karnos BAC Composition of leaf and rhizome essential oils of Hedychium coronarium Koen. from Brazil. J Essent Oil Res. 2010;22:305-6.

110. Joy B, Rajan A, Abraham E. Antimicrobial activity and chemical composition of essential oil from Hedychium coronarium. Phytother Res. 2007;21:439-43.

111. Aziz MA, Habib MR, Karim MR. Antibacterial and cytotoxic activities of Hedychium coronarium J. Koenig. Res J Agric Biol Sci. 2009;5:969-72.

112. Ho JC. Antimicrobial, mosquito larvicidal and antioxidant properties of the leaf and rhizome of Hedychium coronarium. J Chin Chem Soc. 2011;58:563-7.

113. Pandya CV, Jadeja AJ, Golakiya BA. Antifungal activity of crude extracts of Hedychium coronarium. Int J Res Phytochem Pharmacol. 2014;4:4-6.

114. Kaomongkolgit R, Jamdee K, Wongnoi S, Chimnoi N, Techasakul S. Antifungal activity of coronarin D against Candida albicans. Oral Surg Oral Med Oral Pathol Oral Radiol. 2012;114:61-6.

115. Reuk-ngam N, Chimnoi N, Khunnawutmanotham N, Techasakul S. Antimicrobial activity of coronarin $D$ and its synergistic potential with antibiotics. Biomed Res Int. 2014;581985.

116. Valadeau C, Pabon A, Deharo E, Albán-Castillo J, Estevez Y. Medicinal plants from the Yanesha (Peru): evaluation of the leishmanicidal and antimalarial activity of selected extracts. J Ethnopharmacol. 2019;123:413-22. 
117. Kiem PV, Kim Thuy NT, Tuan Anh HL, Nhiem NX, Minh CV. Chemical constituents of the rhizomes of Hedychium coronarium and their inhibitory effect on the pro-inflammatory cytokines production LPS-stimulated in bone marrow-derived dendritic cells. Bioorg Med Chem Lett. 2011;21:7460-5.

118. Shrotriya S, Ali MS, Saha A, Bachar SC, Islam MS. Anti-inflammatory and analgesic effects of Hedychium coronarium Koen. Pak J Pharm Sci. 2007;20:47-51.

119. Lu Y, Zhong CX, Wang L, Lu C, Li XL. Anti-inflammation activity and chemical composition of flower essential oil from Hedychium coronarium. Afr $J$ Biotechnol. 2009;8:5373-7.

120. Dash PR, Nasrin M, Saha MR. Evaluation of analgesic and neuropharmacological activities of methanolic rhizome extract of Hedychium coronarium. Int J Pharma Sci Res. 2011;2(4):979984.

121. Suresh G, Reddy PP, Babu KS, Shaik TB, Kalivendi SV. Two new cytotoxic labdane diterpenes from the rhizomes of Hedychium coronarium. Bioorg Med Chem Lett. 2010;20:7544-8.

122. Zhan ZJ, Wen YT, Ren FY, Rao GW, Shan WG. Diterpenoids and a diarylheptanoid from Hedychium coronarium with significant anti-angiogenic and cytotoxic activities. Chem Biodivers. 2012;9:2754-60.

123. Ray A, Jena S, Dash B, Sahoo A, Kar B. Hedychium coronarium extract arrests cell cycle progression, induces apoptosis, and impairs migration and invasion in HeLa cervical cancer cells. Cancer Manag Res. 2019;11: 483-500.

124. Endringer DC, Taveira FSN, Kondratyuk TP, Pezzuto JM, Braga FC. Cancer chemoprevention activity of labdane diterpenes from rhizomes of Hedychium coronarium. Rev Bras Farmacogn. 2014;24:408-12.

125. Shankar D, Ved DK, Tandon V, Ramesh SR, Karim A, Singh P. Conserving national resource - Need for national policy and national programme on medicinal plant conservation, In: Pushpangadan P, Nair KSS (eds). Pp. 103-117. Biodiversity in tropical forests: the Kerala scenario, Kerala State Committee on Science, Technology and Environment, Kerala, India. 1997.

126. Dash PR, Raihan SZ, Ali MS. Ethnopharmacological investigation of the spice Kaempferia galanga, $1^{\text {st }}$ ed. Lambert Academic Publishing, Saarbrücken, Germany. 2013

127. Preetha TS, Hemanthakumar AS, Krishnan PN. A comprehensive review of Kaempferia galanga L. (Zingiberaceae): a high sought medicinal plant in tropical Asia. J Med Plants Stud. 2016;4:270-6.

128. Shetu HJ, Trisha KT, Sikta SA, Anwar R, Rashed SSB. Pharmacological importance of Kaempferia galanga (Zingiberaceae): a mini review. Int J Res Pharm Pharm Sci. 2018;3:32-9.

129. Tewtrakul S, Yuenyongsawad S, Kummee S, Latthya Atsawajaruwan L. Chemical components and biological activities of volatile oil of Kaempferia galanga Linn. Songklanakarin J Sci Technol. 2005;27:503-7.

130. Umar MI, Asmawi MZB, Sadikun A, Altaf R, Iqbal MA. Phytochemistry and medicinal properties of Kaempferia galanga L. (Zingiberaceae) extracts. Afr J Pharm Pharmacol. 2011;5:1638-47.

131. Parvez MAK, Mahboob HK, Zahurul I, Shek MH. Antimicrobial activities of the petroleum ether, methanol and acetone extracts of Kaempferia galanga L. rhizomes. J Life Earth Sci. 2005;1:25-9.

132. Kochuthressia KP, John Britto $S$, Jaseentha M, Raphae R. In vitro antimicrobial evaluation of Kaempferia galanga L. rhizome extract. Am J Biotechnol Mol Sci. $2011 ; 2: 1-5$

133. Dash PR, Nasrin M, Ali M. In vivo cytotoxic and in vitro antibacterial activities of Kaempferia galanga. J Pharmacogn Phytochem. 2014;3:172-7.

134. Saraswati J, Septalita A, Bovita NA. Antibacterial effect of Kaempferia galanga L extract on Lactobacillus acidophilus - in vitro. Indon J Infect Dis. 2013;1:228.

135. Elya B, Kusuma IM, Jufri M, Handayani R. Antibacterial tests against acne in vitro, the physical stability and patch test using cream containing ethyl pmethoxycinnamate extracted from Kaempferia galanga L. rhizome. Res J Med Plants. 2016;10:426-34.

136. Yang YC, Park IK, Kim EH, Lee HS, Ahn YJ. Larvicidal activity of medicinal plant extracts against Aedes aegypti, Ochlerotatus togoi, and Culex pipiens pallens (Diptera: Culicidae). J Asia Pac Entomol. 2014;7:227-32.

137. Choochote W, Chaithong U, Kamsuk K, Jitpakdi A, Tippawangkosol P Repellent activity of selected essential oils against Aedes aegypti. Fitoterapia. 2007;78:359-64.

138. Dhandapani A, Kumar S, Kadarkarai M. Larvicidal, pupicidal and smoke toxicity effect of Kaempferia galanga to the malarial vector, Anopheles stephensi. Bioscan. 2011;6:329-33

139. Sutthanont N, Choochote W, Tuetun B, Junkum A, Jitpakdi A. Chemical composition and larvicidal activity of edible plant-derived essential oils against the pyrethroid-susceptible and -resistant strains of Aedesaegypti (Diptera: Culicidae). J Vector Ecol. 2011;35:106-15.

140. Liu XC, Liang Y, Shi WP, Liu QZ, Ligang Z. Repellent and insecticidal effects of the essential oil of Kaempferia galanga rhizomes to Liposcelis bostrychophila (Psocoptera: Liposcelidae). J Econ Entomol. 2014;107:1706-712.
141. Dash PR, Mou KM, Erina IN, Ripa FA, Al Masud KN. Study of anthelmintic and insecticidal activities of different extracts of Kaempferia galanga. Int J Pharm Sci Res. 2017;8:729-33

142. Kanjanapothi D, Panthong A, Lertprasertsuke N, Taesotikul T, Rujjanawate C. Toxicity of crude rhizome extract of Kaempferia galanga L. (Proh Hom). J Ethnopharmacol. 2004;90:359-65.

143. Kim NJ, Byun SG, Cho JE, Chung K, Ahn YJ. Larvicidal activity of Kaempferia galanga rhizome phenylpropanoids towards three mosquito species. Pest Manag Sci. 2008;64:857-62.

144. Sulaiman MR, Zakaria ZA, Duad IA, Hidayat MT. Antinociceptive and antiinflammatory activities of the aqueous extract of Kaempferia galanga leaves in animal models. J Nat Med. 2008;62:221-7.

145. Ridtitid W, Sae-Wong C, Reanmongkol W, Wongnawa M. Antinociceptive activity of the methanolic extract of Kaempferia galanga Linn. in experimental animals. J Ethnopharmacol. 2008;118:225-30.

146. Vittalrao AM, Shanbhag T, Kumari M, Bairy KL, Shenoy S. Evaluation of antiinflammatory and analgesic activities of alcoholic extract of Kaempferia galanga in rats. Indian J Physiol Pharmacol. 2011;55:13-24.

147. Taslim NA, Djide MN, Rifai Y, Syahruddin AN, Rampo YR. Double-blind randomized clinical trial of Kaempferia galanga $\mathrm{L}$. extract as an antiinflammation (prostaglandin $\mathrm{E}_{2}$ and tumor necrosis factor-alpha) on osteoarthritis. Asian J Pharm Clin Res. 2019;12:63-6.

148. Umar MI, Asmawi MZ, Sadikun A, Majid AM, Al-Suede FS. Ethyl-pmethoxycinnamate isolated from Kaempferia galanga inhibits inflammation by suppressing interleukin-1, tumor necrosis factor- $\alpha$, and angiogenesis by blocking endothelial functions. Clinics (Sao Paulo). 2014;69:134-44.

149. Huang L, Yagura T, Chen S. Sedative activity of hexane extract of Keampferia galanga L. and its active compounds. J Ethnopharmacol. 2008;120:123-5.

150. Ali MS, Dash PR, Nasrin M. Study of sedative activity of different extracts of Kaempferia galanga in Swiss albino mice. BMC Complement Altern Med. 2015; 15:158.

151. Maas PJM. Renealmia (Zingiberaceae-Zingiberoideae), Costoideae (Additions) (Zingiberaceae). Flora Neotropica. 1977;18:1-218.

152. Otero $R$, Núñez $V$, Jiménez $S L$, Fonnegra $R$, Osorio RG. Snakebites and ethnobotany in the northwest region of Colombia: Part II: neutralization of lethal and enzymatic effects of Bothrops atrox venom. J Ethnopharmacol. 2000;71:505-11.

153. Lans C, Harper T, Georges K, Bridgewater E. Medicinal and ethnoveterinary remedies of hunters in Trinidad. BMC Complement Altern Med. 2011;1:10.

154. Ruysschaert S, Van Andel T, Van de Putte K, Van Damme P. Bathe the baby to make it strong and healthy: plant use and child care among Saramaccan Maroons in Suriname. J Ethnopharmacol. 2009;121:148-70.

155. Lognay G, Marlier M, Severin M, Haugruge E, Gibon V. On the characterization of some terpenes from Renealmia alpinia Rottb. (Mass) oleoresin. Flavour Fragr J. 1991;6:87-91.

156. Zhou BN, Baj NJ, Glass TE, Malone S, Werkhoven MC. Bioactive labdane diterpenoids from Renealmia alpinia collected in the Suriname rainforest. $J$ Nat Prod. 1997;60:1287-93.

157. Yang SW, Zhou BN, Malone S, Werkhoven MC, van Troon F. A new labdane diterpenoid from Renealmia alpinia collected in the Suriname rainforest. J Nat Prod. 1999;62:1173-74.

158. Gilli C, Orlowska E, Kaiser D, Steyrer J, Rathgeb A. Diarylheptanoids, flavonoids and other constituents from two neotropical Renealmia species (Zingiberaceae). Biochem System Ecol. 2014;56:178-84.

159. Núñez V, Otero R, Barona J, Saldarriaga M, Osorio RG. Neutralization of the edema-forming, defibrinating and coagulant effects of Bothrops aspervenom by extracts of plants used by healers in Colombia. Braz J Med Biol Res. 2014;37:969-77.

160. Patiño AC, Benjumea DM, Pereañez JA. Inhibition of venom serine proteinase and metalloproteinase activities by Renealmia alpinia (Zingiberaceae) extracts: comparison of wild and in vitro propagated plants. J Ethnopharmacol. 2013;149:590-6.

161. Gómez-Betancur I, Benjumea D, Patiño A, Jiménez N, Osorio E. Inhibition of the toxic effects of Bothrops aspervenom by pinostrobin, a flavanone isolated from Renealmia alpinia (Rottb.) Maas. J Ethnopharmacol. 2014;155:1609-15.

162. Gómez-Betancur I, Pereañez JA, Patiño AC, Benjumea D. Inhibitory effect of pinostrobin from Renealmia alpinia, on the enzymatic and biological activities of a PLA . Int J Biol Macromol. 2015;89:35-42.

163. Verpoorte R, Tsoi AT, van Doorne H, Svendsen AB. Medicinal plants of Suriname. I. Antimicrobial activity of some medicinal plants. J Ethnopharmacol. 1982;5:221-6.

164. Melo e Silva F, de Paula JE, Espindola LS. Evaluation of the antifungal potential of Brazilian Cerrado medicinal plants. Mycoses. 2009;52:511-7. 
165. Rangel ET. Atividade antiprotozoária, antifúngica e citotóxica de extratos de plantas do bioma Cerrado, com ênfase em Leishmania (Leishmania) chagasi (Antiprotozoal, antifungal, and cytotoxic activities of extracts from plants from the Cerrado biome, with emphasis on Leishmania (Leishmania) chagası). PhD thesis, University of Brasilia, Brasília, Brazil. 2017.

166. De Mesquita ML, de Paula JE, Pessoa C, de Moraes MO, Costa Lotufo LV. Cytotoxic activity of Brazilian Cerrado plants used in traditional medicine against cancer cell lines. J Ethnopharmacol. 2009;123:439-45.

167. Uebelhack R, Franke L, Schewe HL. Inhibition of platelet MAO-B by kava pyrone-enriched extract from Piper methysticum Forster (kava-kava). Pharmacopsychiatry. 1998;31:187-92.

168. Baum SS, Hill R, Rommelspacher H. Effect of kava extract and individual kavapyrones on neurotransmitter levels in the nucleus accumbens of rats. Prog Neuropsychopharmacol Biol Psychiatry. 1998;22:1105-20.

169. Chaurasiya ND, León F, Ding Y, Gómez-Betancur I, Benjumea D. Interactions of desmethoxyyangonin, a secondary metabolite from Renealmia alpinia, with human monoamine oxidase-A and oxidase-B. Evid Based Complement Alternat Med. 2017:4018724.

170. Tzeng YM, Lee MJ. Neuroprotective properties of kavalactones. Neural Regen Res. 2015;10:875-7.

171. Bortolato M, Chen K, Shih JC. Monoamine oxidase inactivation: from pathophysiology to therapeutics. Adv Drug Deliv Rev. 2008;60:1527-33.

172. Svob Strac D, Pivac N, Smolders IJ, Fogel WA, De Deurwaerdere P. Monoaminergic mechanisms in epilepsy may offer innovative therapeutic opportunity for monoaminergic multi-target drugs. Front Neurosci. 2016;10:492.

173. Langner E, Greifenberg S, Gruenwald J. Ginger: history and use. Adv Ther. 1998; 15:25-44.

174. IndexBox. Global Ginger Market 2019 - U.S. Imports Increases Robustly, Turning The Country Into The Most Promising Market. 2019. https://www. globaltrademag.com/global-trade-daily/global-ginger-market-2019-u-simports-increases-robustly-turning-the-country-into-the-most-promisingmarket/.

175. Lawrence BM. Progress in essential oils. Perfumer and Flavorist. 1997;22:7183.

176. Sandeep S.Commentary on therapeutic role of ginger (Zingiber officinale) as medicine for the whole world. Int J Pharmacogn Chinese Med. 2017;1:000102.

177. Imtiyaz S, Rahman K, Sultana A, Tariq M, Chaudhary SS. Zingiber officinale Rosc.: a traditional herb with medicinal properties. TANG. 2013;3:e263.

178. Mekuriya W, Mekibib B. Review on the medicinal values of ginger for human and animal ailments. J Vet Sci Technol. 2010;9:519.

179. Bao L, Deng A, Li Z, Du G, Qin H. Chemical constituents of rhizomes of Zingiber officinale. Zhongguo Zhong Yao Za Zhi. 2010;35:598-601.

180. Jiang H, Solyom AM, Timmermann BN, Gang DR. Characterization of gingerol-related compounds in ginger rhizome (Zingiber oficinale Rosc.) by high-performance liquid chromatography/electrospray ionization mass spectrometry. Rapid Commun Mass Spectrom. 2005;19:2957-64.

181. An K, Zhao D, Wang Z, Wu J, Xu Y, Xiao G. Comparison of different drying methods on Chinese ginger (Zingiber officinale Roscoe): changes in volatiles, chemical profile, antioxidant properties, and microstructure. Food Chem. 2016; 197:1292-300

182. Yamahara J, Rong $\mathrm{HQ}$, Naitoh $\mathrm{Y}$, Kitani T, Fujimura H. Inhibition of cytotoxic drug-induced vomiting in suncus by a ginger constituent. J Ethnopharmacol. 1989;27:353-5.

183. Sharma SS, Kochupillai V, Gupta SK, Seth SD, Gupta YK. Antiemetic efficacy of ginger (Zingiber officinale) against cisplatin-induced emesis in dogs. J Ethnopharmacol. 1997;57:93-6.

184. Sharma SS, Gupta YK. Reversal of cisplatin-induced delay in gastric emptying in rats by ginger. J Ethnopharmacol. 1998;62:49-55.
185. Adbel-Aziz H, Windeck T, Ploch M, Verspohl EJ. Mode of action of gingerols and shogaols on 5-HT3 receptors: binding studies, cation uptake by the receptor channel and contraction of isolated guinea-pig ileum. Eur $J$ Pharmacol. 2006;530:136-43.

186. Sontakke S, Thawani V, Naik MS. Ginger as an antiemetic in nausea and vomiting induced by chemotherapy: a randomized, cross-over, double-blind study. Indian J Pharmacol. 2003;35:32-6.

187. Fahimia F, Khodadad K, Amini S, Naghibi F, Salamzadeh J. Evaluating the effect of Zingiber officinalis on nausea and vomiting in patients receiving cisplatin-based regimens. Iran J Pharm Res. 2011;10:379-84.

188. Pertz HH, Lehmann J, Roth-Ehrang R, Elz S. Effects of ginger constituents on the gastrointestinal tract: role of cholinergic M3 and serotonergic 5-HT3 and 5-HT4 receptors. Planta Med. 2011;77:973-8.

189. Walstab J, Krüger D, Stark T, Hofmann T, Demir IE. Ginger and its pungent constituents non-competitively inhibit activation of human recombinant and native 5-HT3 receptors of enteric neurons. Neurogastroenterol Motil. 2013;25:439-47.

190. Lete I, Allué J. The effectiveness of ginger in the prevention of nausea and vomiting during pregnancy and chemotherapy. Integr Med Insights. 2016;11:11-7.

191. Malu SP, Obochi GO, Tawo EN, Nyong BE. Antibacterial activity and medicinal properties of ginger (Zingiber officinale). Global J Pure Appl Sci. 2009;15:3658.

192. Atai Z, Atapour M, Mohseni M. Inhibitory effect of ginger extract on Candida albicans. Am J Appl Sci. 2009;6:1067-9.

193. Gao D, Zhang Y. Comparative antibacterial activities of crude polysaccharides and flavonoids from Zingiber officinale and processed ginger. Pharmacogn J. 2010;2:41-4.

194. Rahuman AA, Gopalakrishnan G, Venkatesan P, Geetha K, Bagavan A Mosquito larvicidal activity of isolated compounds from the rhizome of Zingiber officinale. Phytother Res. 2008;22:1035-9.

195. Iqbal Z, Nadeem QK, Khan MN, Akhtar MS, Waraich FN. In vitro anthelmintic activity of Allium sativum, Zingiber officinale, Curcurbita mexicana and Ficus religiosa. Int J Agric Biol. 2001;3:454-7.

196. Dubey RD, Verma S, Rane D, Wani VK, Pandey AK. Comparative studies of anthelmintic activity of Zingiber officinale and Cassia tora. Int J Chem Pharm Sci. 2010;1:1-4

197. Lin RJ, Chen CY, Lee JD, Lu CM, Chung LY. Larvicidal constituents of Zingiber officinale (ginger) against Anisakis simplex. Planta Med. 2010;76:1852-58.

198. Raji Y, Udoh US, Oluwadara OO, Akinsomisoye OS, Awobajo O. Antiinflammatory and analgesic properties of the rhizome extract of Zingiber officinale. Afr J Biomed Res. 2002;5:121-4.

199. Yong-liang J, Jun-ming Z, Lin-hui Z, Bao-shan S, Meng-jing B. Analgesic and anti-inflammatory effects of ginger oil. Chin Herb Med 2011;3:150-5.

200. Ezzat SM, Ezzat MI, Okba MM, Menze ET, Abdel-Naim AB. The hidden mechanism beyond ginger (Zingiber officinale Rosc.) potent in vivo and in vitro anti-inflammatory activity. J Ethnopharmacol. 2018;214: 113-23.

201. Tjendraputra E, Tran VH, Liu-Brennan D, Roufogalis BD, Duke CC. Effect of ginger constituents and synthetic analogues on cyclooxygenase-2 enzyme in intact cells. Bioorg Chem. 2001;29:156-63.

202. Jolad SD, Lantz RC, Solyom AM, Chen GJ, Bates RB. Fresh organically grown ginger (Zingiber officinale): composition and effects on LPS-induced PGE production, Phytochemistry. 2004;65:1937-54.

203. Ficker CE, Smith ML, Susiarti S, Leaman DJ, Irawati C. Inhibition of human pathogenic fungi by members of Zingiberaceae used by the Kenyah (Indonesian Borneo). J Ethnopharmacol. 2003;85:289-93.

204. Willenbacher E, Khan SZ, Mujica SCA, Trapani D, Hussain S. Curcumin: new insights into an ancient ingredient against cancer. Int J Mol Sci. 2019;20(8):pii: E1808. 


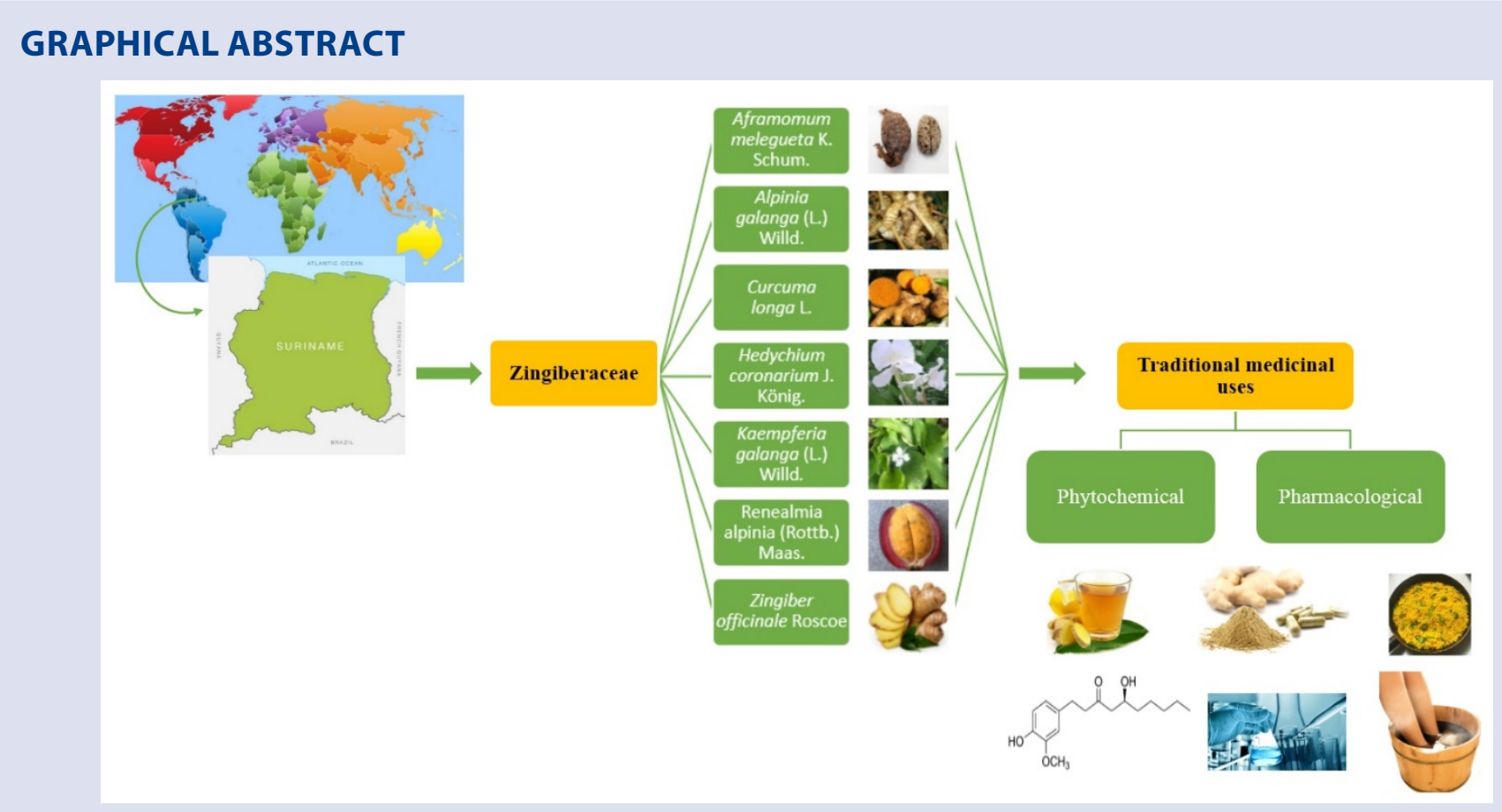

\section{ABOUT AUTHORS}

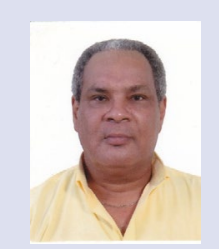

Dennis RA Mans: Dennis Mans is Full Professor of Pharmacology at the Faculty of Medical Sciences of the Anton de Kom University of Suriname, Paramaribo, Suriname. He holds the academic chair in pharmacognosy research. He has more than thirty years of teaching and research experience, particularly in the area of medicinal plants. He has published more than one hundred full papers in international and national journals.

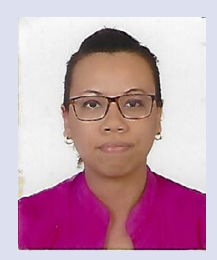

Jennifer Pawirodihardjo: Jennifer Pawirodihardjo has a teaching degree in Chemistry and is working for five years as a chemical analyst at the Faculty of Medical Sciences, Department of Pharmacology, Anton de Kom University of Suriname, Paramaribo, Suriname.

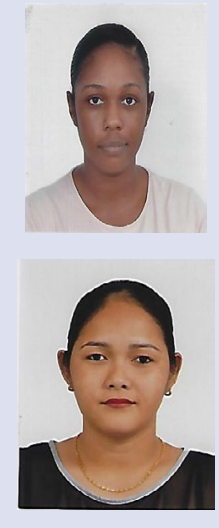

Priscilla Friperson: Priscilla Friperson has studied Higher Laboratory Sciences at the Polytechnic College and is working as a chemical analyst at the Faculty of Medical Sciences, Department of Pharmacology, Anton de Kom University of Suriname, Paramaribo, Suriname.

Meryll Djotaroeno: Meryll Djotaroeno has a BTech degree in Higher Laboratory Sciences and is working as a chemical analyst at the Faculty of Medical Sciences, Department of Pharmacology, Anton de Kom University of Suriname, Paramaribo, Suriname.

Cite this article: Mans DRA, Djotaroeno M, Friperson P, Pawirodihardjo J. Phytochemical and Pharmacological Support for the Traditional Uses of Zingiberacea Species in Suriname - A Review of the Literature. Pharmacog J. 2019;11(6)Suppl:1511-25. 